University of Nebraska - Lincoln

DigitalCommons@University of Nebraska - Lincoln

1982

\title{
Aftershocks of the Coyote Lake, California, Earthquake of August 6, 1979' A Detailed Study
}

P. Reasenberg

U.S. Geological Survey

W. L. Ellsworth

U.S. Geological Survey

Follow this and additional works at: https://digitalcommons.unl.edu/usgsstaffpub

Part of the Earth Sciences Commons

Reasenberg, P. and Ellsworth, W. L., "Aftershocks of the Coyote Lake, California, Earthquake of August 6, 1979' A Detailed Study" (1982). USGS Staff -- Published Research. 385.

https://digitalcommons.unl.edu/usgsstaffpub/385

This Article is brought to you for free and open access by the US Geological Survey at DigitalCommons@University of Nebraska - Lincoln. It has been accepted for inclusion in USGS Staff -- Published Research by an authorized administrator of DigitalCommons@University of Nebraska - Lincoln. 


\title{
Aftershocks of the Coyote Lake, California, Earthquake of August 6, 1979: A Detailed Study
}

\author{
P. Reasenberg and W. L. Ellsworth \\ U.S. Geological Survey, Menlo Park, California 94025
}

\begin{abstract}
Aftershock hypocenters and focal mechanism solutions for the Coyote Lake, California, earthquake reveal a geometrically complex fault structure, consisting of multiple slip surfaces. The faulting surface principally consists of two right stepping en echelon, northwest trending, partially overlapping, nearly vertical sheets and is similar in geometry to a slip surface inferred for the 1966 Parkfield, California, earthquake. The overlap occurs near a prominent bend in the surface trace of the Calaveras fault at San Felipe Lake. Slip during the main rupture, as inferred from the distribution of early aftershocks, appears to have been confined to a $14-\mathrm{km}$ portion of the northeastern sheet between $4-$ and $10-\mathrm{km}$ depth. Focal mechanisms and the hypocentral distribution of aftershocks suggest that the main rupture surface itself is geometrically complex, with left stepping imbricate structure. Seismic shear displacement on the southwestern slip surface commenced some 5 hours after the mainshock. Aftershocks in this zone define a single vertical plane $8 \mathrm{~km}$ long between $3-$ and $7-\mathrm{km}$ depth. Within the overlap zone between the two main slip surfaces, the average strike of aftershock nodal planes is significantly rotated clockwise relative to the strike of the fault zone, in close agreement with the stress perturbations predicted by crack interaction models. Aftershock activity in the overlap zone is not associated with a simple dislocation surface. Space and time clustering within the entire aftershock set suggest an alternation of seismic displacement between the component parts of the fault zone. This alternation is consistent with local stress perturbations predicted by crack interaction models. We conclude that the fault structure is geometrically complex and that the displacements that occur on its component surfaces during the aftershock process dynamically interact by generating perturbations in the local stress field which, in turn, control the displacements.
\end{abstract}

\section{INTRODUCTION}

On August 6, 1979, a widely felt earthquake occurred near Coyote Lake within the Calaveras fault zone, about $12 \mathrm{~km}$ northeast of the city of Gilroy, California (Figure 1). This earthquake $\left(\mathrm{M}_{L}=5.9, M_{S}=5.7\right)$ was the strongest within the San Andreas fault system within the latitude of the $M 8 \frac{1}{4}$ 1906 earthquake since at least 1911 . Although the earthquake produced only very minor surficial offsets [Lee et al., 1979], trilateration surveys (M. Lisowski and N. E. King, unpublished data, 1982) and aftershock studies [Lee et al., 1979; Uhrhammer, 1980] indicate that right-lateral displacements occurred at depth along an approximately $20-\mathrm{km}$ segment of the Calaveras fault extending from Coyote Lake south into the Hollister trough. The earthquake also produced a remarkable suite of near-field strong-motion records, including two from instruments located within $10 \mathrm{~km}$ of the epicenter [Brady et al., 1981]. These records, when combined with farfield seismograms, place significant constraints on the dynamic rupture [Bouchon, 1982; Nabelek and Toksöz, 1981] and thus complement static models of the earthquake obtained from geodetic data [King et al., 1981; M. Lisowski and N. E. King, unpublished data, 1982].

In this paper we study the geometry of this earthquake, as revealed by its aftershock hypocenters and their focal mechanisms, and examine its relationship to the dynamic rupture, the static displacement field, and the mapped surface expression of the fault zone. The availability of an accurately measured suite of $P$ wave travel time data $( \pm 0.01 \mathrm{~s})$ from a dense local network permits us to resolve the structure of the hypocentral zone in three dimensions on a length scale of about $250 \mathrm{~m}$. The highly precise locations derived from these

This paper is not subject to U.S. copyright. Published in 1982 by the American Geophysical Union.

Paper number 2B1361. data reveal structural features that depart significantly from simple planar models of fault zones and earthquakes but agree well with theoretical models of crack interaction [Segall and Pollard, 1980]. Hypocenter data of comparable quality from the 10-year period before the earthquake also permit us to examine the relationship of this earthquake to long-lived features of the seismicity and possibly to enduring features of the fault itself.

Previous studies of aftershock sequences for strike slip earthquakes in central California by Eaton et al. [1970] and Ellsworth [1975] have shown that, to first order, moderatesized earthquakes ( $M$ 5-6) involve slip on nearly vertical, essentially planar zones. In detail, some complexity in the fault plane geometry is suggested by these studies, particularly in the case of the 1966 Parkfield earthquake (see also Lindh and Boore [1981]). Other studies [Bakun, 1980; Bakun et al., 1980] have suggested fault plane models with geometric complexities inferred from the distribution of accumulated seismic moment along faults in central California. However, the location precision has previously not been adequate to resolve the nature of the complexities. Extension of hypocentral resolution to smaller length scales allows more detailed slip surface models to be considered. In this paper we will consider the implications of the Coyote Lake observations for several specific, detailed geometric models of faults.

\section{EARTHQUAKE LOCATIONS}

The Coyote Lake earthquake was located in the central part of the region covered by the U.S. Geological Survey's central California microearthquake network. Seismograph stations in operation since 1969 provide adequate geometric control for the resolution of the epicenter and depth of virtually all earthquakes of magnitude 1.5 and greater in this region (Figure 2). Precision of epicenter is limited in routine 


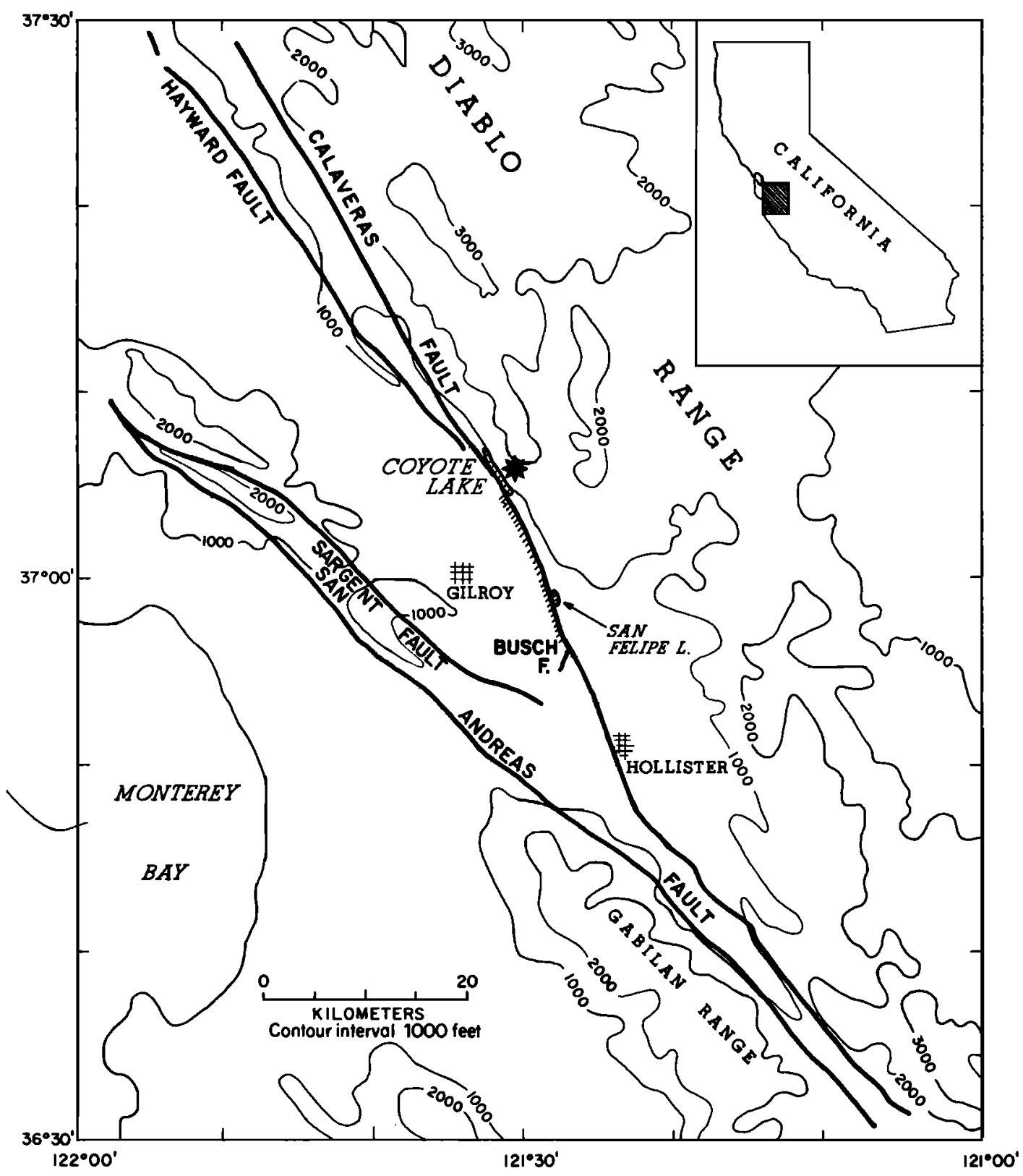

Fig. 1. Map showing generalized topography and location of the major faults in the area of the August 6, 1979, Coyote Lake, California, earthquake. The mainshock epicenter is indicated by the star. The portion of the Calaveras fault sustaining intermittent surface faulting is indicated by hachures. Elevation contours are in feet.

analysis by a combination of timing precision, nominally $0.05 \mathrm{~s}$ [Reasenberg, 1980], and crustal model control. To overcome these limitations, we have analyzed digital seismograms obtained from FM tape recordings and have developed a specialized crustal velocity model for the aftershock region. The seismograms were digitized at 100 samples per second and read to the nearest sample on an interactive graphics terminal. Such data potentially permit the resolution of local hypocentral differences of a few tens of meters [Poupinet et al., 1982; Spieth, 1981]. A locally optimized crustal model was developed from travel time data from a subset of the earthquakes and from three calibration shots (Figure 2) using an interactive least squares procedure similar to that used by Crosson [1976].

The comparatively small dimensions of the aftershock zone $(20 \mathrm{~km})$ when compared to the dimensions of the station set used to locate the earthquakes $(100 \mathrm{~km})$ accounts for the success that a simple homogeneous plane-parallel layered model (Table 1), augmented by station corrections (Table 2), has in explaining these travel time data. The rootmean-square (rms) travel time residuals for earthquakes located with this model average $0.07 \mathrm{~s}$ and are significantly smaller than those obtained from more regional velocity models. Because the residuals significantly exceed the reading error, estimated to be $0.02 \mathrm{~s}$ [Reasenberg, 1980], it is probable that a significant portion of the unexplained travel time variance is controlled by small-scale crustal heterogeneity within the source region. The rms average of the standard errors in epicenter and depth are $0.26 \mathrm{~km}$ and 0.45 $\mathrm{km}$, respectively, for all events located with this model.

Thurber [1981] successfully recovered significant firstorder three-dimensional features from the same data set 


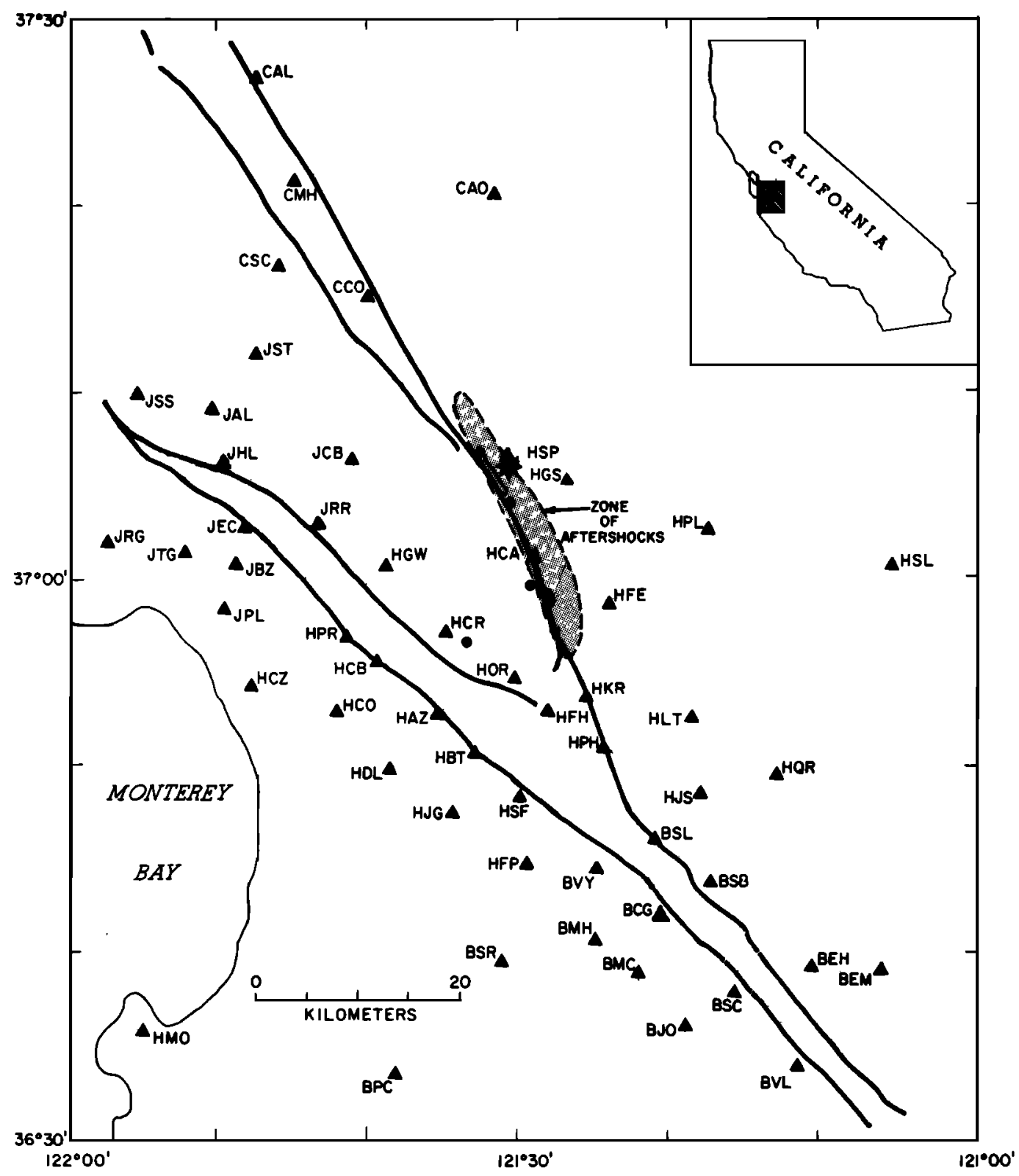

Fig. 2. Map showing the locations (solid triangles) of the seismograph stations used in this study. The mainshock epicenter is indicated by the star. The shaded area indicates the zone of aftershock epicenters. Solid circles mark sites of calibration shots.

analyzed here by inverting travel time data for velocity structure and source locations using three-dimensional raytracing methods. The hypocentral distribution that he obtained using full three-dimensional methods is similar to the result presented here (compare Figure 3 with Figure 5.15 of Thurber [1981]). Because these results are in good agreement and have comparable residual variance, we are confident that the relative hypocenter locations obtained here with a comparatively simple model are not significantly distorted by local crustal heterogeneity. The question of the absolute position of these events, however, cannot be decided with the data available. The locations obtained for two different sets of station corrections (Table 2), shown in Figures 3 and 4 , satisfy the travel time data equally well and display nearly identical epicentral distributions. The difference in focal depths between sets seen in Figure 4 is controlled by the choice of station corrections, which are different for the two models. This illustrates that the depths are not absolutely determined either.

The aftershock zone grossly divides into three parts: a northern, apparently east dipping zone (I) that bounds the sequence on the northeast side and is located generally north of $37^{\circ} \mathrm{N}$; a nearly vertical, shallower zone (II) that bounds the sequence on the southwest side and is located generally south of $37^{\circ} \mathrm{N}$; and a diffuse zone (III) that lies between zones I and II (Figures $3 b$ and $4 b$ ).

Location set $A$ in Figures $3 a$ and $4 a$ was obtained from the travel time inversion with all epicenters allowed to move freely and with shot points held fixed at their true locations. All epicenters located in this manner fall well to the east of the fault. The three shots relocated with this model fall, on average, $0.5 \mathrm{~km}$ northeast of their true locations. Events in the steeply dipping northern group, zone I, possibly could be projected updip to intersect the surface near the surface 
TABLE 1. Layered Velocity Structure (Model B)

\begin{tabular}{cc}
\hline $\begin{array}{c}\text { Velocity, } \\
\mathrm{km} / \mathrm{s}\end{array}$ & $\begin{array}{c}\text { Depth to } \\
\text { Top of } \\
\text { Layer, } \mathrm{km}\end{array}$ \\
\hline 4.842 & 0.00 \\
5.391 & 1.50 \\
5.695 & 3.00 \\
5.889 & 4.25 \\
6.132 & 5.50 \\
6.198 & 6.75 \\
6.276 & 8.00 \\
6.407 & 10.00 \\
6.500 & 12.50 \\
\hline
\end{tabular}

trace of the fault, which could account, in part, for the apparent epicentral bias. However, the position of the southern vertical zone II cannot be reconciled in this manner with the active fault trace that it parallels.

In set $\mathrm{B}$ (Figures $3 b$ and $4 b$; Table $5^{1}$, listing locations of mainshock and aftershocks) the events in zone II are presumed to lie in a vertical plane directly below the surface trace of the fault, and these events were constrained to remain in this plane during the modeling. Free solutions for all events were determined once the model was established. The calibration shots relocated with this model fall, on average, $0.8 \mathrm{~km}$ southwest of their true locations. Given the simplicity of our crustal model, we cannot discriminate between the two models on a purely statistical basis, but we prefer set B on the basis of the imposed geophysical constraint. Thurber's [1981] three-dimensional location results also place the southern vertical zone beneath the fault trace. Consequently, we shall interpret only set $B$ in the remainder of the paper.

In all, 321 aftershocks that were analyzed from digital records, and 759 earthquakes, $M \geq 1.5$, from January 1 , 1969 , to February 9, 1981, that were timed from Develocorder film records have been relocated using model $\mathrm{B}$. Although the latter set of locations is not as precise as the former, it agrees extremely well with the aftershock locations from the digital data (compare Figure $12 b$ with Figure $3 b)$.

\section{Focal Mechanisms}

The mainshock and 76 aftershocks were recorded with clear first motions on a sufficient number of stations to allow well-constrained modeling of fault plane solutions. Equalarea stereographic projections of first-motion polarities on the lower half of the focal sphere provided the basis of conventional modeling of the fault plane solutions. The mainshock and virtually all the aftershocks studied are best modeled by strike slip solutions (Figure 5).

First-motion readings at stations located near the Calaveras fault clearly show the effect of lateral refraction, as has been described by McNally and McEvilly [1977]. Polarity readings for the mainshock, for example, cannot be fit by any northwest striking plane unless allowance is made for laterally refracted ray paths to stations BSL, CAL, CMH, HCA, CCO, HJS, HKR, and HPH (Figure 2). Discrepancies such as these can be used to estimate the average velocity

\footnotetext{
${ }^{1}$ Table 5 is available with entire article on microfiche. Order from American Geophysical Union, 2000 Florida Avenue, N.W., Washington, D.C. 20009. Document J82-006; \$1.00. Payment must accompany order.
}

contrast across the Calaveras fault in this area. Following the approach of McNally and McEvilly [1977], the velocity is found to be $3 \pm 1 \%$ higher to the northeast of the fault than it is to the southwest, in agreement with Thurber's [1981] three-dimensional model. This velocity contrast, which is not completely modeled by station corrections in the location procedure, could account for the northeasterly offset of the epicenters of model A from the suface trace of the fault. Healy and Peake [1975] found a similar contrast across the San Andreas fault in the Bear Valley region where standard locations also fall about $1 \mathrm{~km}$ into the higher-velocity medium (see also Engdahl and Lee [1976]).

TABLE 2. Station Corrections

\begin{tabular}{|c|c|c|c|c|}
\hline Station & $\begin{array}{c}\text { Latitude, } \\
\text { North }\end{array}$ & $\begin{array}{c}\text { Longitude, } \\
\text { West }\end{array}$ & $\begin{array}{c}\text { Model A } \\
\text { Delay(s) }\end{array}$ & $\begin{array}{l}\text { Model B } \\
\text { Delay(s) }\end{array}$ \\
\hline CÁLV & $37^{\circ} 27.07^{\prime}$ & $121^{\circ} 47.95^{\prime}$ & 0.75 & 0.71 \\
\hline CAOV & $37^{\circ} 20.96^{\prime}$ & $121^{\circ} 31.96^{\prime}$ & 0.54 & 0.37 \\
\hline $\mathrm{CCOV}$ & $37^{\circ} 15.46^{\prime}$ & $121^{\circ} 40.35^{\prime}$ & 1.00 & 0.99 \\
\hline CMHV & $37^{\circ} 21.57^{\prime}$ & $121^{\circ} 45.38^{\prime}$ & 0.90 & 0.88 \\
\hline CSCV & $37^{\circ} 17.11^{\prime}$ & $121^{\circ} 46.35^{\prime}$ & 0.89 & 0.93 \\
\hline JALV & $37^{\circ} 9.50^{\prime}$ & $121^{\circ} 50.82^{\prime}$ & 0.19 & 0.34 \\
\hline JBZV & $37^{\circ} 01.07^{\prime}$ & $121^{\circ} 49.15^{\prime}$ & 0.65 & 0.84 \\
\hline JCBV & $37^{\circ} 6.71^{\prime}$ & $121^{\circ} 41.33^{\prime}$ & 0.17 & 0.29 \\
\hline JECV & $37^{\circ} 3.04^{\prime}$ & $121^{\circ} 48.56^{\prime}$ & 0.30 & 0.49 \\
\hline JHLV & $37^{\circ} 6.56^{\prime}$ & $121^{\circ} 49.95^{\prime}$ & 0.18 & 0.34 \\
\hline JPLV & $36^{\circ} 58.62^{\prime}$ & $121^{\circ} 49.93^{\prime}$ & 0.72 & 0.93 \\
\hline JRGV & $37^{\circ} 2.22^{\prime}$ & $121^{\circ} 57.86^{\prime}$ & 0.45 & 0.64 \\
\hline JRRV & $37^{\circ} 3.27^{\prime}$ & $121^{\circ} 43.61^{\prime}$ & 0.07 & 0.25 \\
\hline JSSV & $37^{\circ} 10.17^{\prime}$ & $121^{\circ} 55.84^{\prime}$ & 0.17 & 0.32 \\
\hline JSTV & $37^{\circ} 12.41^{\prime}$ & $121^{\circ} 47.84^{\prime}$ & 0.26 & 0.35 \\
\hline JTGV & $37^{\circ} 1.71^{\prime}$ & $121^{\circ} 52.58^{\prime}$ & 0.61 & 0.80 \\
\hline HAZV & $36^{\circ} 53.08^{\prime}$ & $121^{\circ} 35.45^{\prime}$ & 0.70 & 0.86 \\
\hline HBTV & $36^{\circ} 51.01^{\prime}$ & $121^{\circ} 33.04^{\prime}$ & 0.93 & 1.07 \\
\hline HCAV & $37^{\circ} 1.52^{\prime}$ & $121^{\circ} 29.02^{\prime}$ & 0.32 & 0.28 \\
\hline HCBV & $36^{\circ} 55.88^{\prime}$ & $121^{\circ} 39.63^{\prime}$ & 0.45 & 0.64 \\
\hline $\mathrm{HCOV}$ & $36^{\circ} 53.19^{\prime}$ & $121^{\circ} 42.20^{\prime}$ & 0.57 & 0.76 \\
\hline HCRV & $36^{\circ} 57.46^{\prime}$ & $121^{\circ} 35.01^{\prime}$ & 0.09 & 0.24 \\
\hline $\mathrm{HCZV}$ & $36^{\circ} 54.54^{\prime}$ & $121^{\circ} 48.02^{\prime}$ & 0.58 & 0.77 \\
\hline HDLV & $36^{\circ} 50.12^{\prime}$ & $121^{\circ} 38.64^{\prime}$ & 0.49 & 0.66 \\
\hline HFEV & $36^{\circ} 59.00^{\prime}$ & $121^{\circ} 24.09^{\prime}$ & 0.35 & 0.17 \\
\hline HFHV & $36^{\circ} 53.29^{\prime}$ & $121^{\circ} 28.13^{\prime}$ & 0.61 & 0.66 \\
\hline HFPV & $36^{\circ} 45.22^{\prime}$ & $121^{\circ} 29.43^{\prime}$ & 0.71 & 0.78 \\
\hline HGSV & $37^{\circ} 5.75^{\prime}$ & $121^{\circ} 26.83^{\prime}$ & 0.37 & 0.15 \\
\hline HGWV & $37^{\circ} 1.02^{\prime}$ & $121^{\circ} 39.02^{\prime}$ & 0.10 & 0.30 \\
\hline HJGV & $36^{\circ} 47.88^{\prime}$ & $121^{\circ} 34.43^{\prime}$ & 0.63 & 0.75 \\
\hline HJSV & $36^{\circ} 48.99^{\prime}$ & $121^{\circ} 17.92^{\prime}$ & 0.58 & 0.45 \\
\hline HKRV & $36^{\circ} 54.10^{\prime}$ & $121^{\circ} 25.56^{\prime}$ & 0.82 & 0.77 \\
\hline HLTV & $36^{\circ} 53.07^{\prime}$ & $121^{\circ} 18.49^{\prime}$ & 0.43 & 0.26 \\
\hline HMOV & $36^{\circ} 36.03^{\prime}$ & $121^{\circ} 55.06^{\prime}$ & 0.39 & 0.53 \\
\hline HORV & $36^{\circ} 55.03^{\prime}$ & $121^{\circ} 30.46^{\prime}$ & 0.38 & 0.48 \\
\hline HPHV & $36^{\circ} 51.38^{\prime}$ & $121^{\circ} 24.37^{\prime}$ & 0.98 & 0.94 \\
\hline HPLV & $37^{\circ} 3.13^{\prime}$ & $121^{\circ} 17.40^{\prime}$ & 0.39 & 0.08 \\
\hline HPRV & $36^{\circ} 57.19^{\prime}$ & $121^{\circ} 41.70^{\prime}$ & 0.38 & 0.58 \\
\hline HQRV & $36^{\circ} 50.02^{\prime}$ & $121^{\circ} 12.76^{\prime}$ & 0.57 & 0.40 \\
\hline HSFV & $36^{\circ} 48.72^{\prime}$ & $121^{\circ} 29.97^{\prime}$ & 1.01 & 1.09 \\
\hline HSLV & $37^{\circ} 1.16^{\prime}$ & $121^{\circ} 5.13^{\prime}$ & 0.55 & 0.26 \\
\hline HSPV & $37^{\circ} 06.91^{\prime}$ & $121^{\circ} 30.94^{\prime}$ & 0.40 & 0.32 \\
\hline BCGV & $36^{\circ} 42.55^{\prime}$ & $121^{\circ} 20.60^{\prime}$ & 0.96 & 0.93 \\
\hline BEHV & $36^{\circ} 39.88^{\prime}$ & $121^{\circ} 10.45^{\prime}$ & 0.66 & 0.55 \\
\hline BEMV & $36^{\circ} 39.68^{\prime}$ & $121^{\circ} 5.76^{\prime}$ & 0.66 & 0.54 \\
\hline BJOV & $36^{\circ} 36.65^{\prime}$ & $121^{\circ} 18.81^{\prime}$ & 0.64 & 0.61 \\
\hline BMCV & $36^{\circ} 39.40^{\prime}$ & $121^{\circ} 21.92^{\prime}$ & 0.70 & 0.69 \\
\hline BMHV & $36^{\circ} 41.17^{\prime}$ & $121^{\circ} 24.80^{\prime}$ & 0.62 & 0.66 \\
\hline BPCV & $36^{\circ} 33.90^{\prime}$ & $121^{\circ} 38.15^{\prime}$ & 0.56 & 0.67 \\
\hline BSBV & $36^{\circ} 44.27^{\prime}$ & $121^{\circ} 17.21^{\prime}$ & 0.84 & 0.75 \\
\hline BSCV & $36^{\circ} 38.50^{\prime}$ & $121^{\circ} 15.59^{\prime}$ & 1.01 & 0.93 \\
\hline BSLV & $36^{\circ} 46.53^{\prime}$ & $121^{\circ} 20.96^{\prime}$ & 0.87 & 0.81 \\
\hline BSRV & $36^{\circ} 39.99^{\prime}$ & $121^{\circ} 31.12^{\prime}$ & 0.51 & 0.60 \\
\hline BVLV & $36^{\circ} 34.51^{\prime}$ & $121^{\circ} 11.34^{\prime}$ & 0.98 & 0.90 \\
\hline BVYV & $36^{\circ} 44.96^{\prime}$ & $121^{\circ} 24.80^{\prime}$ & 0.95 & 0.96 \\
\hline
\end{tabular}



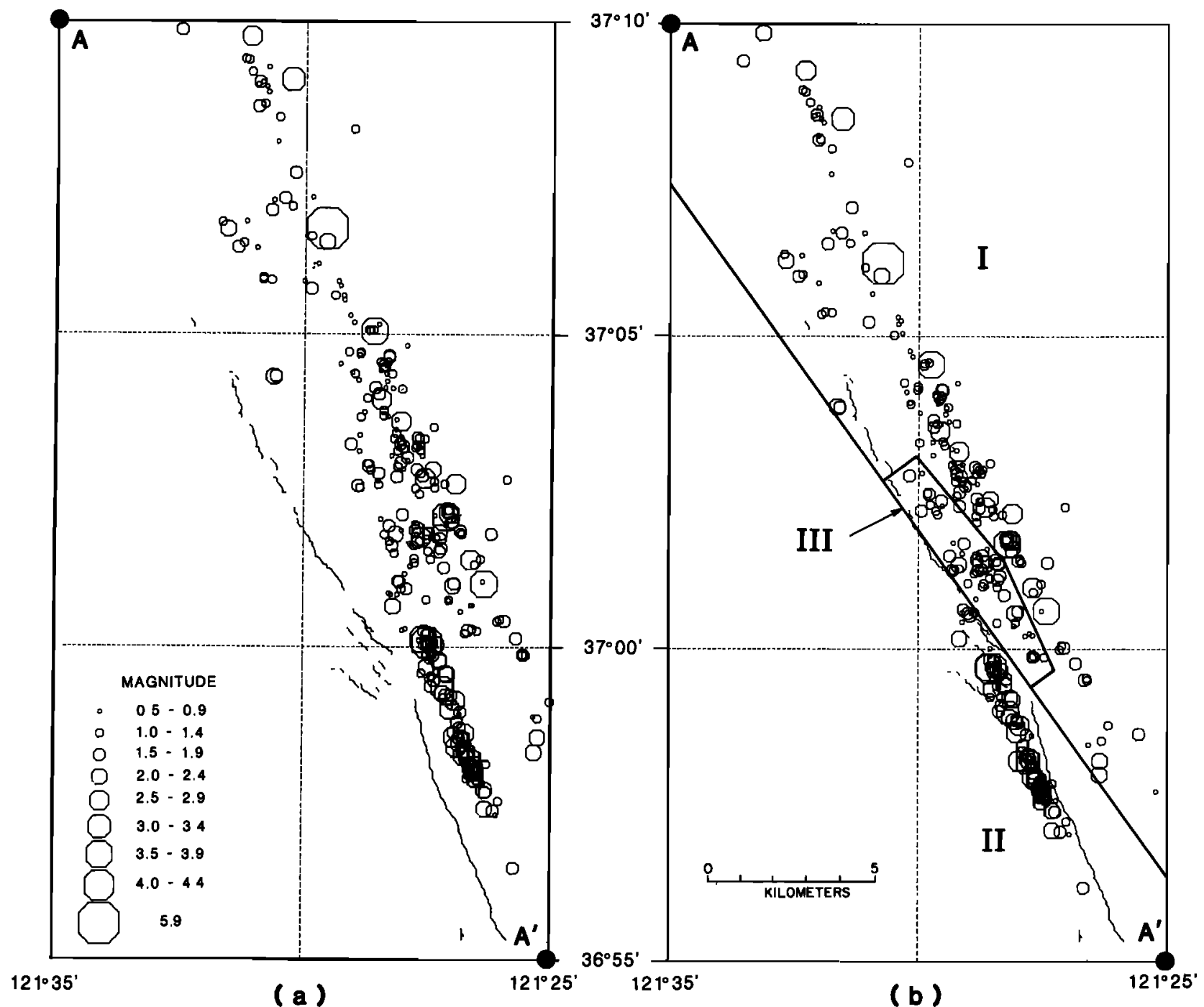

Fig. 3. Epicenters of the aftershock set determined with locally optimized crustal models. Solid and broken lines indicate the surface trace of the Calaveras fault mapped by D. G. Herd (unpublished data, 1982). (a) Location set A, obtained with an unconstrained model. (b) Location set B, obtained with a model that constrains some hypocenters to the fault plane (see text). Aftershock zones I, II, and III are indicated by heavy straight-line segments.

The focal mechanism solution for the mainshock obtained from local first-motion data (strike $\mathrm{N} 30^{\circ} \pm 5^{\circ} \mathrm{W}$, dip $80^{\circ} \pm$ $5^{\circ} \mathrm{NE}$, slip vector $180^{\circ} \pm 20^{\circ}$ ) is in good agreement with teleseismic modeling results of Nabelek and Toksöz [1981] $\left(\mathrm{N} 37^{\circ} \mathrm{W}, 80^{\circ} \mathrm{NE}, 1^{\circ}\right)$ and with the local and teleseismic modeling results of Liu and Helmberger [1981] (strike $\mathrm{N} 24^{\circ} \mathrm{W}$, dip $80^{\circ} \mathrm{NE}$ ) (Table 3). These solutions agree reasonably with the local strike of the fault of $N 27^{\circ} \mathrm{W}$. The prominent lineations of the epicentral clusters in zones I and II (Figure 3) strike $\mathrm{N} 25^{\circ} \mathrm{W}$ and $\mathrm{N} 22^{\circ} \mathrm{W}$ and $\operatorname{dip} 80^{\circ} \mathrm{NE}$ and $90^{\circ}$, respectively.

Among the aftershocks the average strike of the right-slip nodal planes is $\mathrm{N} 22^{\circ} \mathrm{W}$, which roughly agrees with the average strike of the Calaveras fault in the immediate area. There are systematic differences in focal mechanism orientation among the epicentral zones, and within zones I and II relative to both the mean orientation of each hypocentral zone and to the local strike of the fault trace. These differences are not considered artifacts of the identified lateral velocity contrast, because, owing to its symmetry, the effect of the contrast on a ray's position on the focal sphere is symmetric with respect to the auxiliary plane, while a rotation in strike of a strike slip focal mechanism solution is asymmetric. In addition, rays passing near the auxiliary nodal plane are unaffected by the contrast. The average strike of dextral nodal planes in zone $I$ is rotated $5^{\circ}$

TABLE 3. Mainshock Focal Mechanism

\begin{tabular}{llll}
\hline \multicolumn{1}{c}{ Source } & \multicolumn{1}{c}{ Strike } & \multicolumn{1}{c}{ Dip } & \multicolumn{1}{c}{ Slip } \\
\hline $\begin{array}{l}\text { Calnet data } \\
\text { Nabelek and Toksöz }\end{array}$ & $\mathrm{N} 30^{\circ} \pm 5^{\circ} \mathrm{W}$ & $80^{\circ} \pm 5^{\circ} \mathrm{NE}$ & $180^{\circ} \pm 20^{\circ}$ \\
$\quad$ & & & \\
$\quad$ First & & & \\
Second & $\mathrm{N} 37^{\circ} \mathrm{W}$ & $80^{\circ} \mathrm{NE}$ & $174^{\circ}$ \\
$\quad$ Total & $\mathrm{N} 30^{\circ} \mathrm{W}$ & & \\
Uhrhammer [1980] & $\mathrm{N} 32^{\circ} \mathrm{W}$ & $81^{\circ} \mathrm{NE}$ & $173^{\circ}$ \\
$\begin{array}{l}\text { Lee et al. [1979] } \\
\text { Liu and Helm- }\end{array}$ & $\mathrm{N} 27^{\circ} \pm 7^{\circ} \mathrm{W}$ & $90^{\circ} \pm 15^{\circ}$ & \\
$\quad$ & $\mathrm{N} 24^{\circ} \mathrm{W}$ & $90^{\circ}$ & $180^{\circ}$ \\
$\quad$ berger [1981] & & $80^{\circ} \mathrm{NE}$ & \\
\hline
\end{tabular}



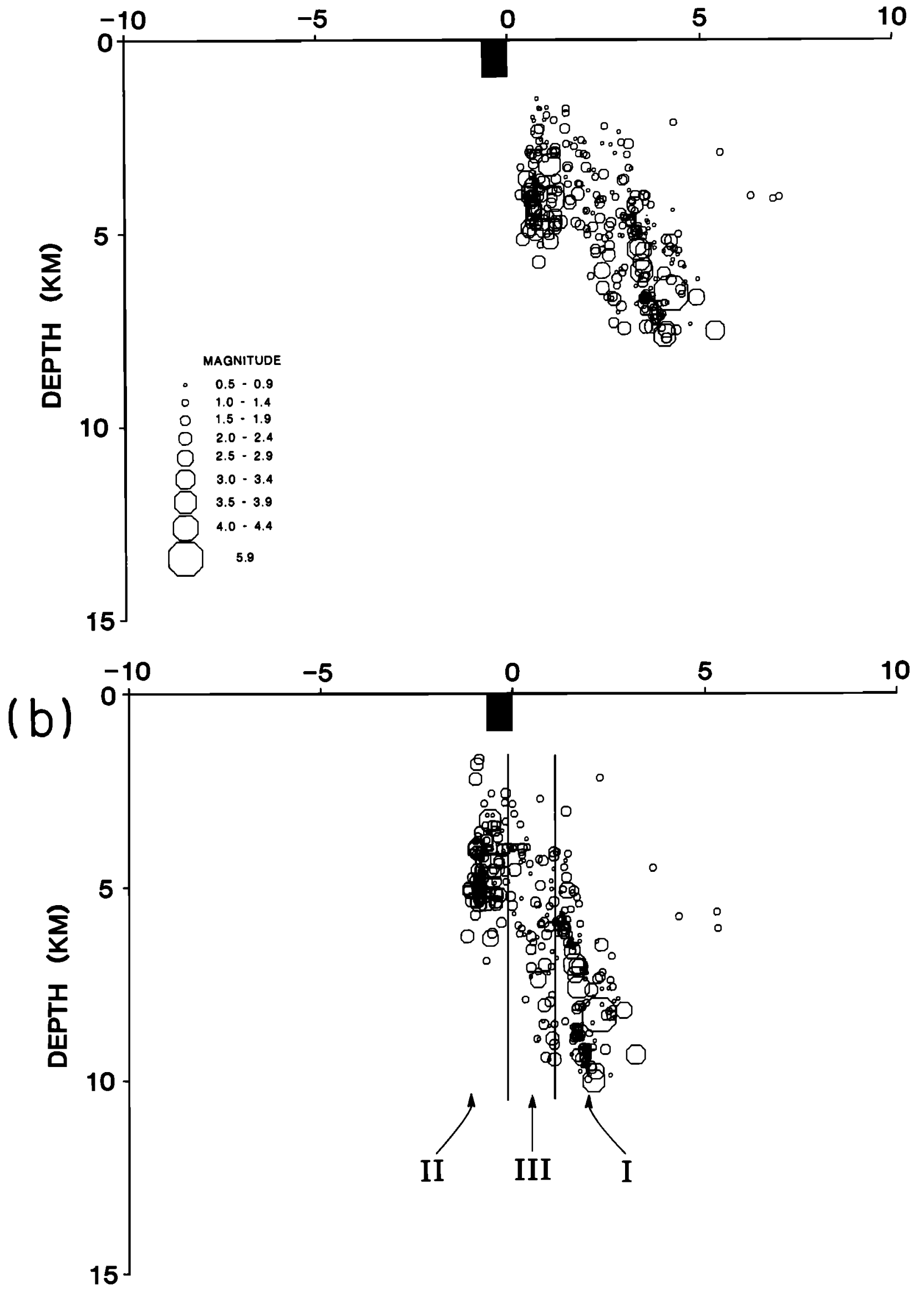

Fig. 4. Hypocenters of the aftershock set projected onto vertical planes perpendicular to the line segments $A-A^{\prime}$ in Figure 3. The view is from the southeast. (a) Location set A. (b) Location set B. Approximate boundaries between aftershock zones are indicated by straight-line segments. The area containing the surface trace of the Calaveras fault is indicated by the shaded patch. 


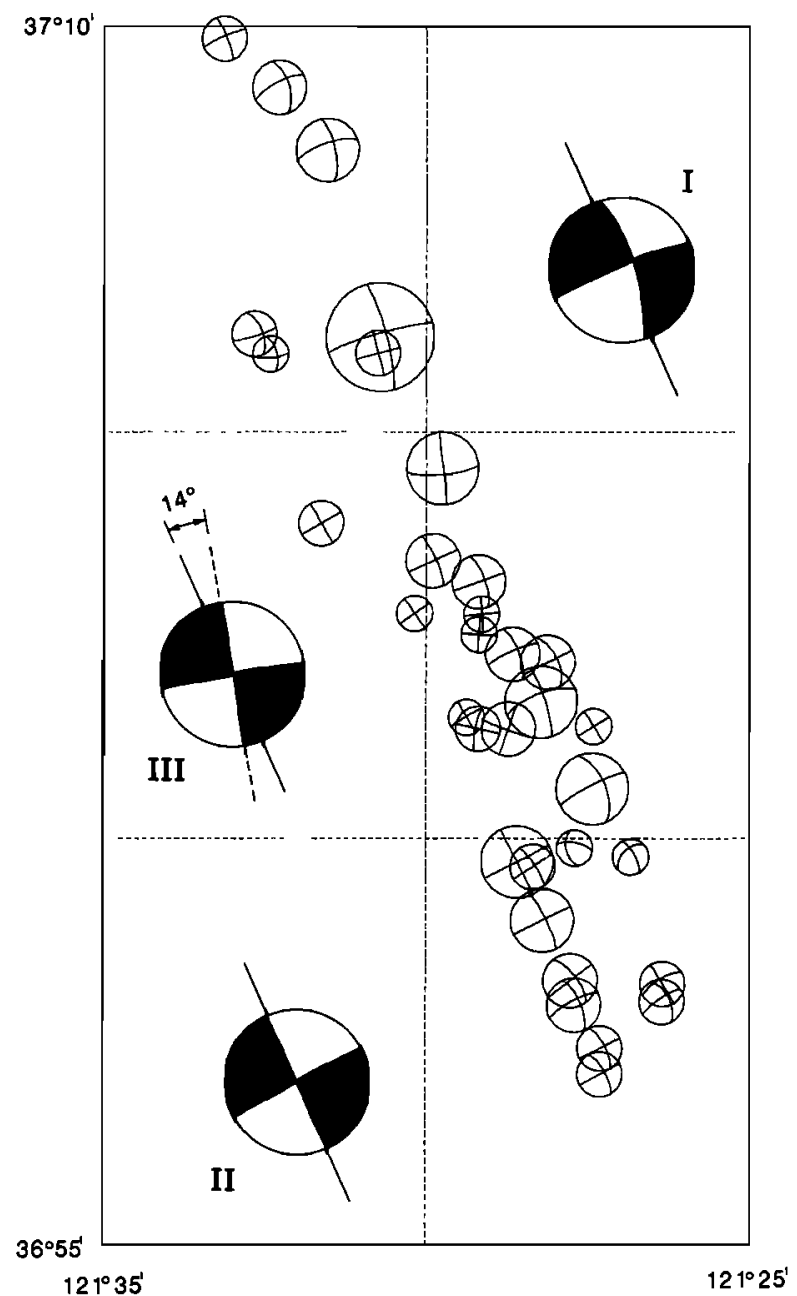

Fig. 5. Map of lower hemisphere equal-area projections of fault plane solutions for the mainshock and selected aftershocks. Averages of solution parameters for the three epicentral zones (Figure $3 b$ ) are indicated by the large solution diagrams with compressional quadrants shaded solid. The average strike of the fault planes in zones I and II ( $\left.24^{\circ} \mathrm{W}\right)$ is indicated by solid lines on the composite solution diagrams. The average strike of the fault planes in zone III $\left(\mathrm{N} 10^{\circ} \mathrm{W}\right)$ is indicated by the dashed line.

$\pm 2^{\circ}$ clockwise relative to the average strike of the hypocentral cluster (Table 4). In zone II this relationship is $5^{\circ} \pm 2^{\circ}$ counterclockwise. Similar results are obtained if the local strikes of the surface trace are used for reference. In zone III the average strike of dextral nodal planes is rotated $15^{\circ} \pm 6^{\circ}$ and $12^{\circ} \pm 6^{\circ}$ clockwise relative to the strikes of the hypocentral clusters in zones $I$ and II, respectively. The average strike of dextral nodal planes in zone III is rotated $14^{\circ} \pm 7^{\circ}$ clockwise relative to that for the aftershocks in zones I and II combined (Figure 5). The figures of merit cited above for average strikes of sets of nodal planes are standard deviations of the mean for the set. Corresponding figures of merit for the sets based on the subjectively assessed uncertainty in each estimate of nodal plane strike are smaller.

\section{GeOMETRY OF THE AfTERSHOCK ZoNe}

In general terms, the aftershock distribution of the Coyote Lake earthquake appears to be typical of a strike slip earthquake. The hypocenters define a relatively narrow zone that is elongated within the plane of the fault. Focal mecha- nisms are generally concordant with continued slip on the fault. The majority of the aftershocks, and in particular the larger events, preferentially locate on the periphery of zone I (Figure 6). In fact, very few events locate within about $5 \mathrm{~km}$ of the mainshock hypocenter, suggesting that the prominent concentration of aftershocks that surrounds it marks a zone of stress concentration produced by the mainshock, while the interior quiet zone delineates the main region of stress release in the earthquake. The rough dimensions of the mainshock indicated by this observation agree well with the estimates derived from analysis of its body waves, whereas the total dimension of the aftershock zone does not [Nabelek and Toksöz, 1981; Bouchon, 1982; Liu and Helmberger, 1981].

While the Coyote Lake aftershock zone generally conforms to the assumed picture of continuing slip on a simple planar surface that is initiated by the stress redistribution of the mainshock, it is apparent upon closer examination that the geometry involved is more complex. The aftershock hypocenters clearly suggest the presence of multiple slip surfaces within the Calaveras fault zone. At the largest scale, in zones I and II, there appear to be two northwest trending approximately planar and nearly parallel surfaces defined by the aftershocks (Figures 3 and 4). Between them (zone III), extending from approximately $37^{\circ} \mathrm{N}$ to $37^{\circ} 3^{\prime} \mathrm{N}$, a third, subparallel strand is also apparent. These features are more readily seen in stereoscopic projection (Figure 7).

The prominent sheet of hypocenters in zone I bounds the entire sequence on the northeast and contains the mainshock hypocenter. Fault plane solutions for these events (Figure 8) support the interpretation of this feature as a comparatively simple, steeply east dipping planar surface. The clockwise rotation of the average strike of dextral fault planes relative to the hypocentral distribution and fault trace suggests left stepping imbrication. In Figure $7 b$, hypocentral clusters within zone I suggest the presence of two or three left steps, seen at the latitude of two small left steps in the surface trace.

Seismicity within zone II, principally to the south of $37^{\circ} \mathrm{N}$, forms a thin, nearly vertical sheet with right-slip nodal planes lying within the plane of the hypocentral trend (Figure 8). The rms distance of hypocenters from a vertical plane imbedded in the cluster is $0.17 \mathrm{~km}$. Slight variations in the strike of some fault plane solutions suggest local imbrication, branching, or warping of the zone (Figure 9). While such features are probably below the resolution of the focal mechanism data, the hypocentral data have sufficient precision to test for such fine-scale structure. Figure $7 b$ suggests the presence of a single right step at $36^{\circ} 58.8^{\prime} \mathrm{N}$. The fact that the transverse distance from the mean trend of zone $\mathrm{II}$ is smoothly contoured (Figure 9) supports the interpretation of either low-amplitude warping or imbrication. The fact that

TABLE 4. Averages of Fault Plane Solutions

\begin{tabular}{llll}
\hline & \multicolumn{1}{c}{ Zone I } & \multicolumn{1}{c}{ Zone II } & \multicolumn{1}{c}{ Zone III } \\
\hline Mean fault plane strike & $\mathrm{N} 20^{\circ} \pm 2^{\circ} \mathrm{W}$ & $\mathrm{N} 27^{\circ} \pm 2^{\circ} \mathrm{W}$ & $\mathrm{N} 10^{\circ} \pm 6^{\circ} \mathrm{W}$ \\
$\begin{array}{l}\text { Mean fault plane dip } \\
76^{\circ} \pm 2^{\circ} \mathrm{NE}\end{array}$ & $85^{\circ} \pm 2^{\circ} \mathrm{NE}$ & $90^{\circ} \pm 6^{\circ}$ \\
$\begin{array}{c}\text { Number of fault plane } \\
\begin{array}{c}\text { solutions } \\
\text { Mean strike of hypo- }\end{array}\end{array}$ & $\mathrm{N} 25^{\circ} \pm 1^{\circ} \mathrm{W}$ & $\mathrm{N} 22^{\circ} \pm 1^{\circ} \mathrm{W}$ & 10 \\
$\begin{array}{c}\text { central cluster } \\
\text { Strike of surface trace }\end{array}$ & $\mathrm{N} 28.5^{\circ} \pm 1^{\circ} \mathrm{W}$ & $\mathrm{N} 25^{\circ} \pm 1^{\circ} \mathrm{W}$ & \\
\hline
\end{tabular}




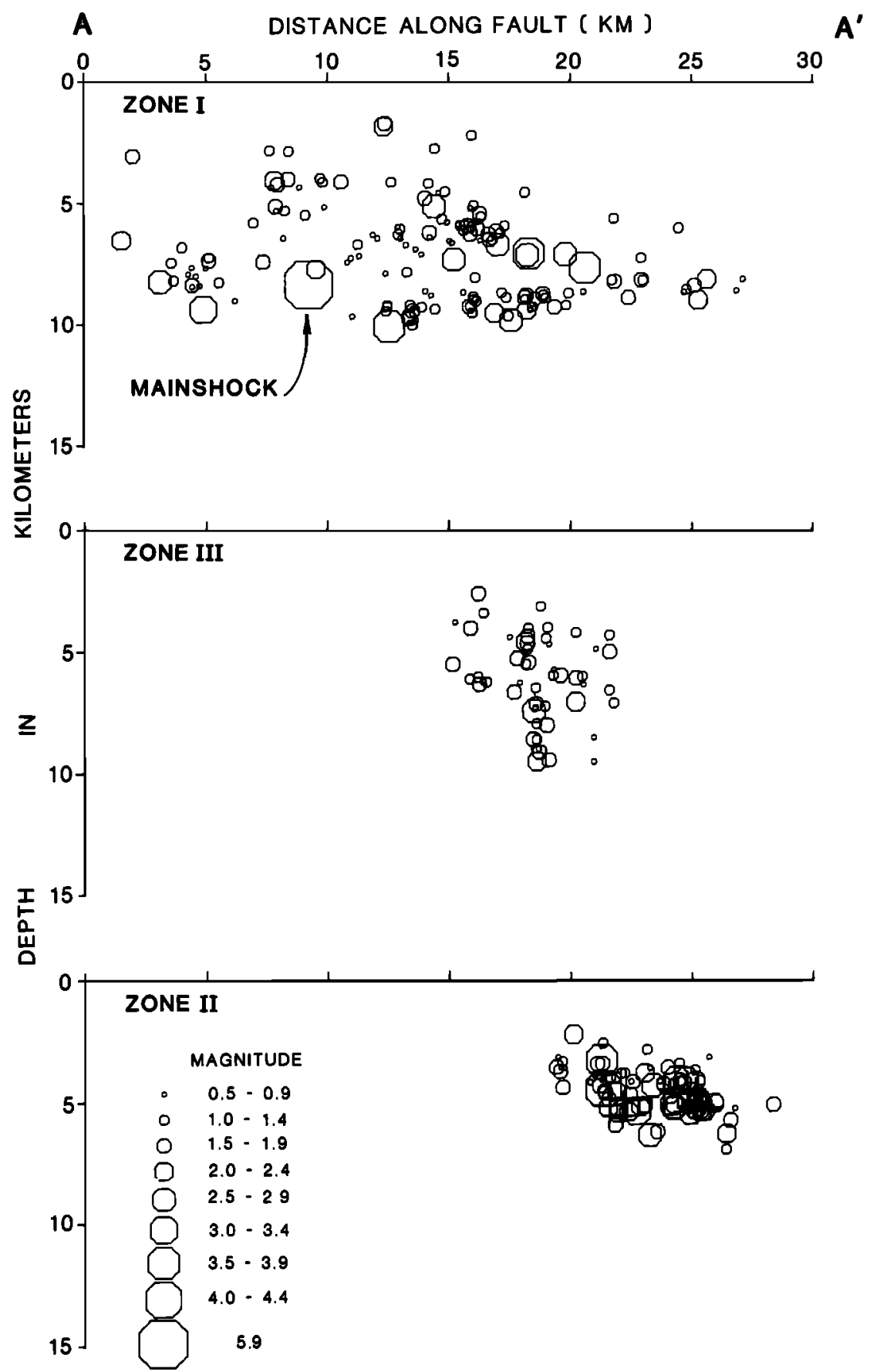

Fig. 6. Hypocenters of the mainshock and aftershock set projected onto a vertical plane extending below the line segment $A-A^{\prime}$ in Figure 3 . Views are from the southwest. Events in epicentral zones I, III, and II are shown separately.

the average strike of the dextral fault planes in this zone is slightly rotated counterclockwise relative to the hypocentral trend favors right stepping imbrication on a scale at or just below the hypocentral resolution. However, we would caution that such structure might be an artifact produced by model-dependent errors. For example, as we have shown above (Figure 3), the epicentral position in the transverse direction is a strong function of the station corrections to the crustal model. Localized variations in the $3 \%$ velocity contrast across the fault could plausibly produce the result of Figure 9. Consequently, we must conclude that in the scale length range between a few hundred meters and several kilometers the zone II activity cannot be distinguished from a single plane.

In zone III, the interpretation of a northwest striking plane lying immediately west of the mainshock surface, as suggested by the hypocentral distribution, is not supported by the focal mechanism solutions. Most of the events in zone III for which we have focal mechanisms crosscut the trend of the entire zone. These complications, which are apparent in the stereoscopic views, in Figure $8 b$ in particular, suggest that events in zone III many originate on splays emanating from the mainshock surface either as low-angle dextral shears, as illustrated, or as high-angle sinistral shears. However, linear 


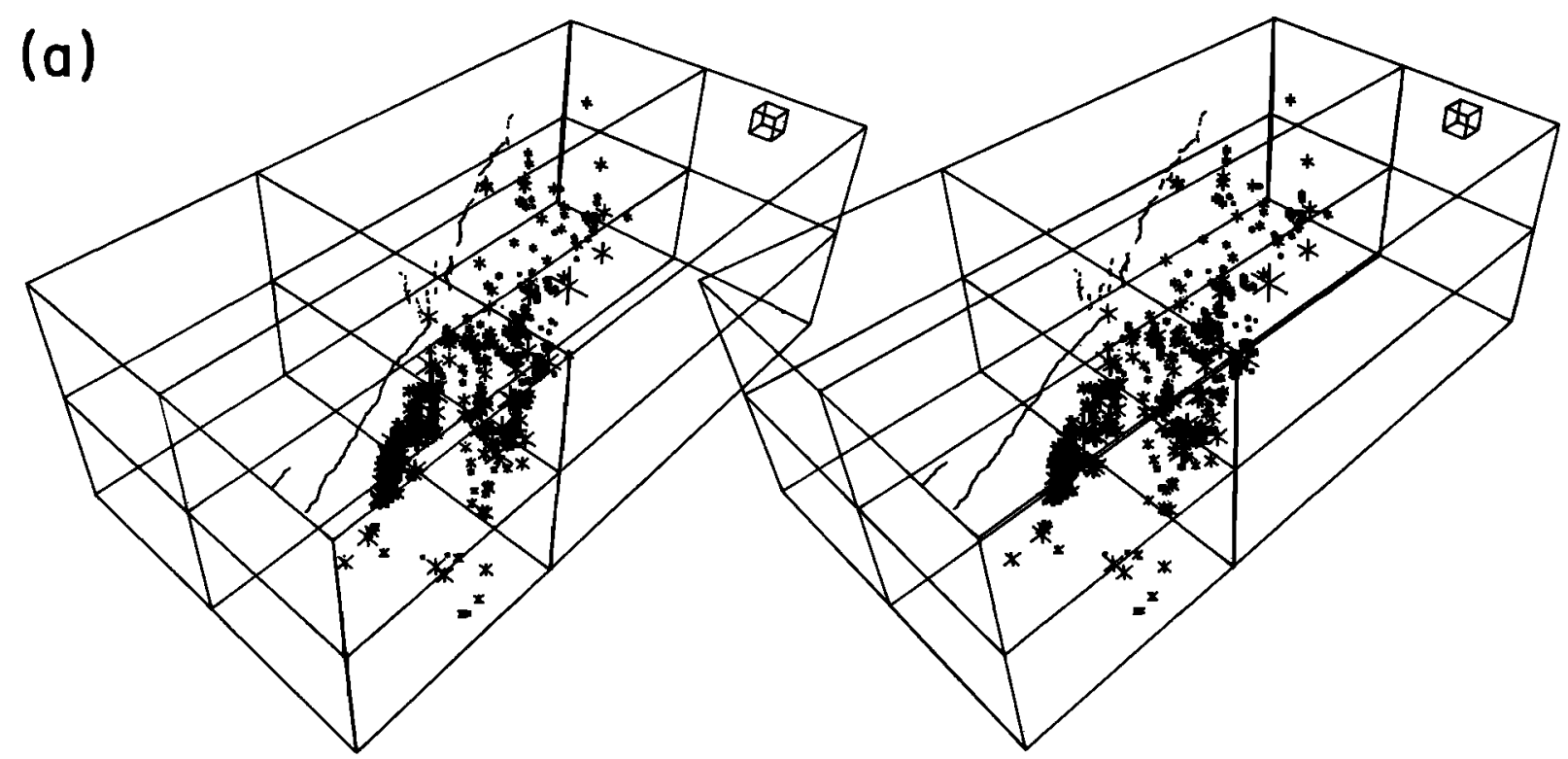

(b)
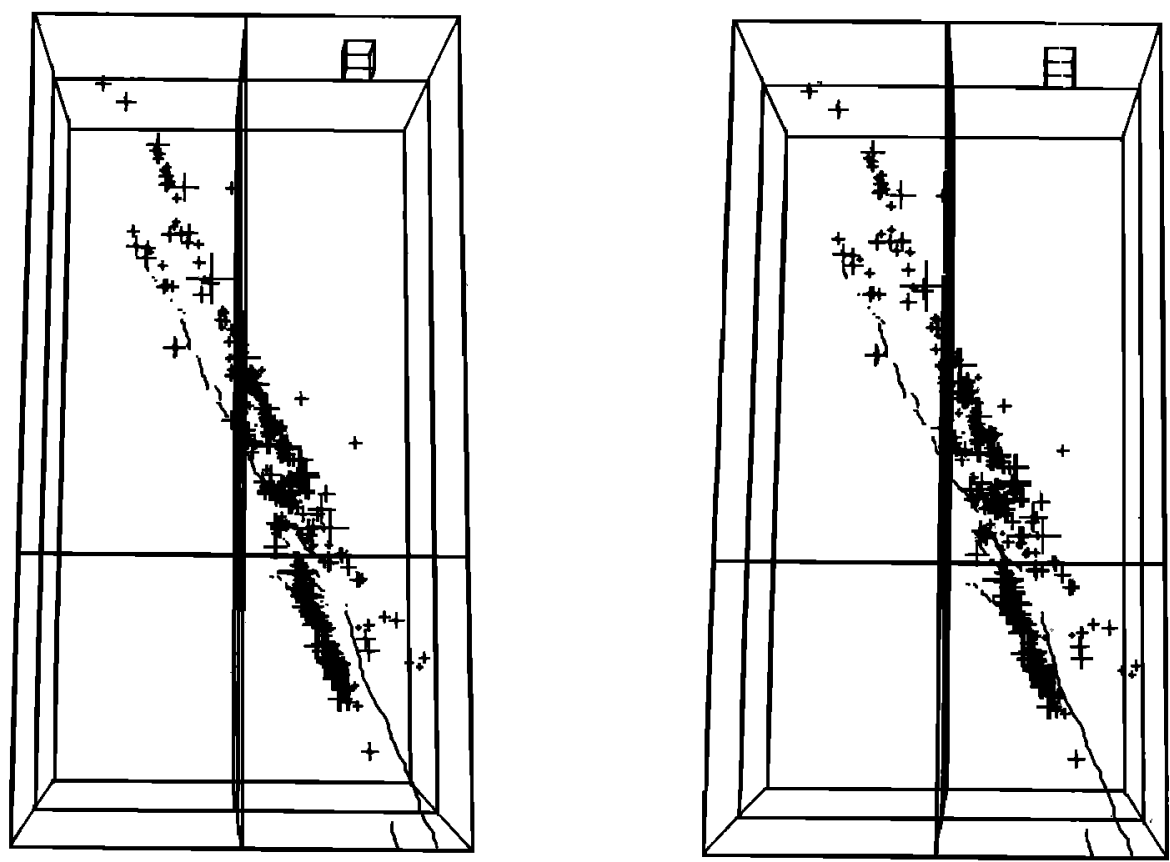

Fig. 7. Stereoscopic views of location set $B$ (Figures $3 b$ and $4 b$ ). Hypocenters are indicated by jack symbols proportional in size to magnitude. The box is bounded by $36^{\circ} 55^{\prime} \mathrm{N}, 37^{\circ} 10^{\prime} \mathrm{N}, 121^{\circ} 25^{\prime} \mathrm{W}$, and $121^{\circ} 35^{\prime} \mathrm{W}$, between the surface and 10-km depth, with intermediate divisions shown at $37^{\circ} \mathrm{N}, 121^{\circ} 30^{\prime} \mathrm{W}$ and $5-\mathrm{km}$ depth. The trace of the Calaveras fault mapped by D. G. Herd (unpublished data, 1982) is shown on the surface. A cube with $1-\mathrm{km}$ sides is shown for reference. (a) View from the southeast, $(b)$ View from above. The stereoscopic projections in Figures 7 and 8 were prepared using a computer program written by German and Johnson [1982] and can be viewed with an ordinary stereoscope.

clustering of hypocenters aligned with the strikes of these mechanisms is not apparent in zone I or III.

In overview, the aftershock zone can be generally described as two roughly planar dislocation surfaces that are offset by a $2-\mathrm{km}$ right step near their facing tips. Virtually all of the seismicity lies on the bounding planes or in the zone between them. Focal mechanisms for earthquakes on the two main planes conform with horizontal strike slip motion 


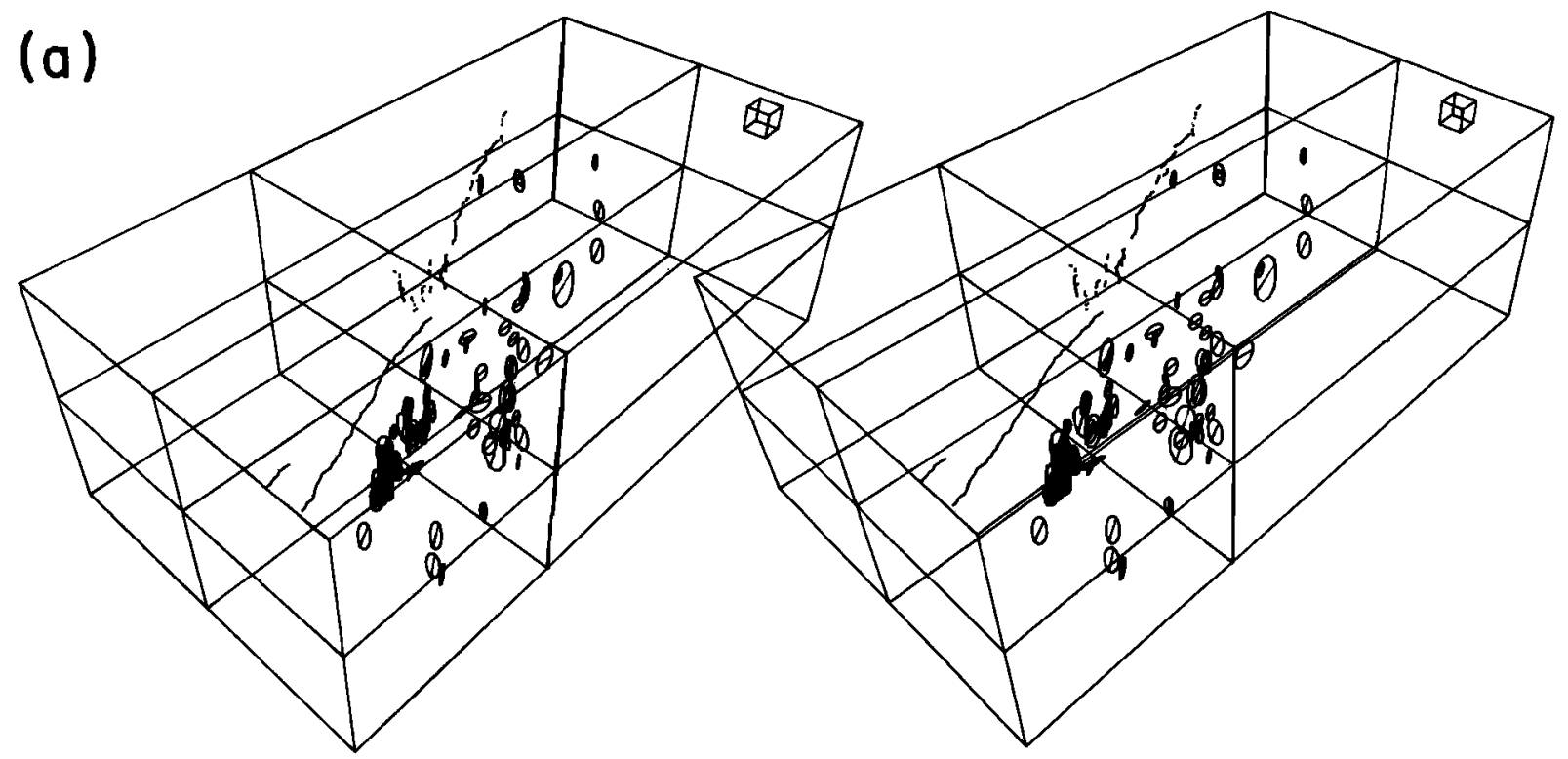

(b)
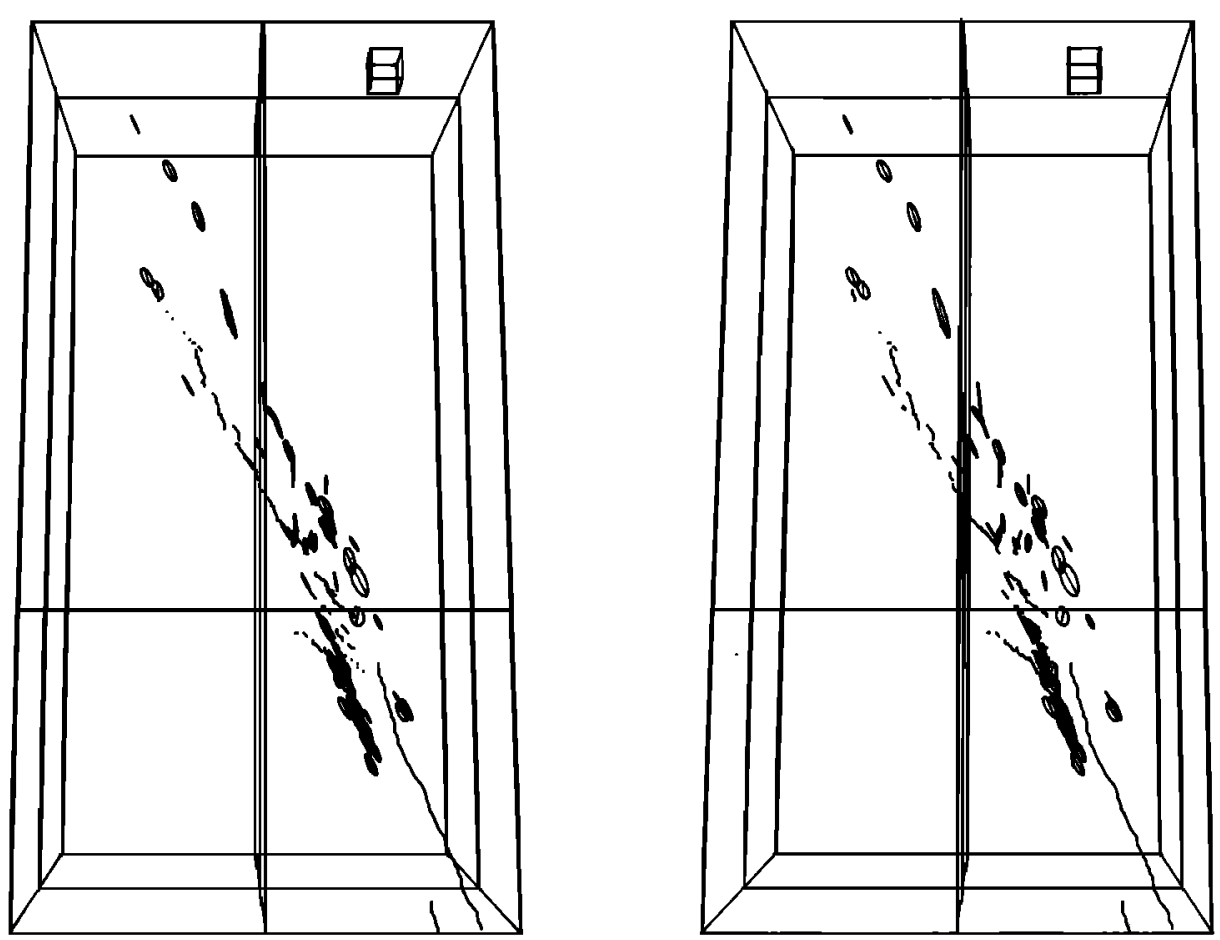

Fig. 8. Stereoscopic views of fault plane solutions for the mainshock and 76 aftershocks. Each circle symbol, centered on a hypocenter, is oriented in the plane of slip. The diameter indicates the direction of slip. Symbol size is proportional to magnitude. A cube with 1-km sides is shown for reference. See Figure 7 for further explanation.

across them. Complications in hypocentral clustering and focal mechanism orientation suggest a complex geometry of the slip surface in zone I. Left stepping imbrication is consistent with these observations. Aftershock activity within zone III (the interior zone) generally crosscuts the step and is not unambiguously associated with a particular fault geometry.

The location of the right step in the aftershock zone correlates well with the position of a major complication in the surface trace of the fault (Figures 1 and 3). This compli- 


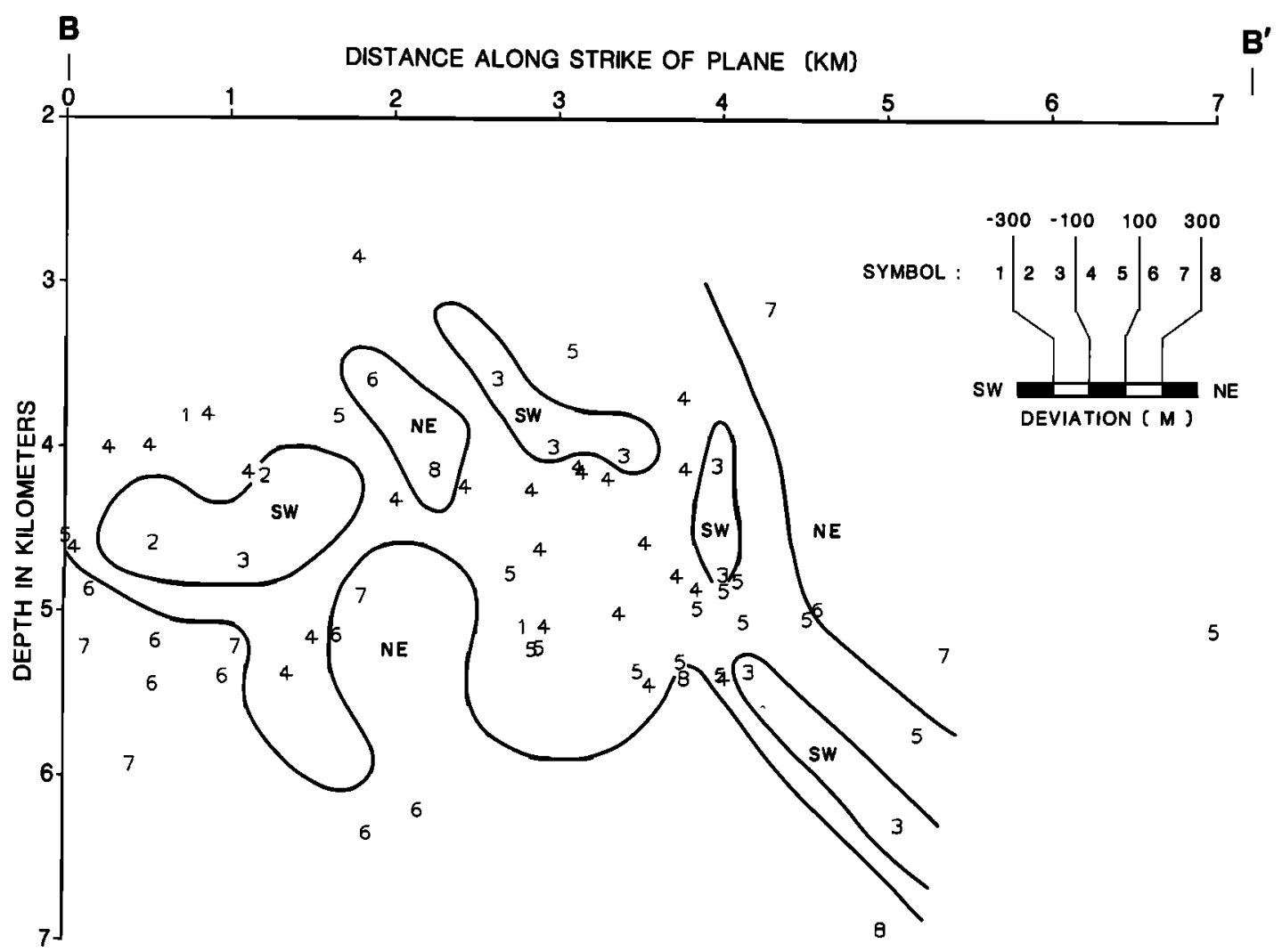

Fig. 9. Deviation of zone II aftershock locations from a vertical reference plane embedded in the hypocenter distribution. Endpoints of the intersection of the plane with the surface are indicated by $B\left(37^{\circ} \mathrm{N}, 121^{\circ} 27.41^{\prime} \mathrm{W}\right)$ and $\mathrm{B}^{\prime}$ $\left(36^{\circ} 56.34^{\prime} \mathrm{N}, 121^{\circ} 25.75^{\prime} \mathrm{W}\right)$. The view is from the southwest. The symbol shown corresponds to distance from the vertical reference plane in 100-m units. Both 100-m (northeast) and $-100-\mathrm{m}$ (southwest) contours are shown. Patches deviating from the reference plane $100 \mathrm{~m}$ or more northeast or southwest are labeled NE and SW, respectively.

cation at San Felipe Lake marks the point where the fault trace emerges from the Hollister trough and climbs onto the western foothills of the Diablo Range that flank the Santa Clara Valley on the east. As the fault trace leaves the Hollister trough, its strike is deflected to the west, while the deeper activity at this point shifts to the east. A concentration in accumulated seismic moment for the aftershocks near this surface complication led Bakun [1980] to infer the presence of a right stepping offset of the slip surface. Thus while there is good agreement between the gross structural features, there does not appear to be a simple geometric relationship between the finer features in the surface expression of the fault and structures inferred at depth.

\section{Temporal Development of the Aftershock Zone}

During the first 18 months of the sequence the rate of aftershock occurrence $\left(M_{L} \geq 1.5\right)$ as a function of time closely follows an inverse power law

$$
(d / d t) n(t)=c t^{-h}
$$

(Figure 10). The maximum likelihood estimate of $h$ was determined, using the method of Page [1968], to be $h=0.73$ \pm 0.04 (314 events, 95\% confidence). After 18 months the rate of earthquakes had returned to the 10-year background level (for $M_{L} \geq 1.5$ ) of 3.6 events per month. Corresponding rates for the aftershocks in zone I and zone II also closely follow an inverse power law. Maximum likelihood estimates of $h$ were separately determined (95\% confidence) for the events in these zones to be $h=0.65 \pm 0.07$ (163 events) and $h=0.96 \pm 0.09$ (82 events), respectively.

For a detailed view of the space-time evolution of the aftershock sequence, hypocenter set $B$ is preferable to the 18-month set because both its inclusion of small $\left(M_{L}<1.5\right)$ events and its high hypocentral precision allow greater resolution of space-time patterns in the sequence. Over the 60 -day period the length of the active portion of zone I increases bilaterally from $14 \mathrm{~km}$ during the first few hours to $25 \mathrm{~km}$ after 60 days. Activity in zone II gradually migrates toward the southeast. Separate plots of the space-time evolution of the sequence for the three epicentral zones (Figure 11) reveal distinctly different patterns of development and suggest significant dynamic interaction of the slip surfaces.

During the first 5.5 hours, aftershock epicenters are essentially confined to zone I from $5 \mathrm{~km}$ northwest to $9 \mathrm{~km}$ southeast of the mainshock epicenter. Most of the larger of these events occur below 7-km depth southeast of the mainshock epicenter. Some shallow activity occurs in zone III at this time. After the occurrence of the largest aftershock in the sequence $\left(M_{L}=4.0\right.$; August 6, $\left.2233 \mathrm{UT}\right)$, zone II activates above 7-km depth, zone III activity intensifies, and the deep activity in zone $I$ extends further to the southeast. During the interval from 1 to 9 days after the mainshock, aftershocks in the central portion of zone I completely cease (see also Figure 6). Activity in zones II and III continues to decay at constant rate. Deep aftershocks in the southeast 


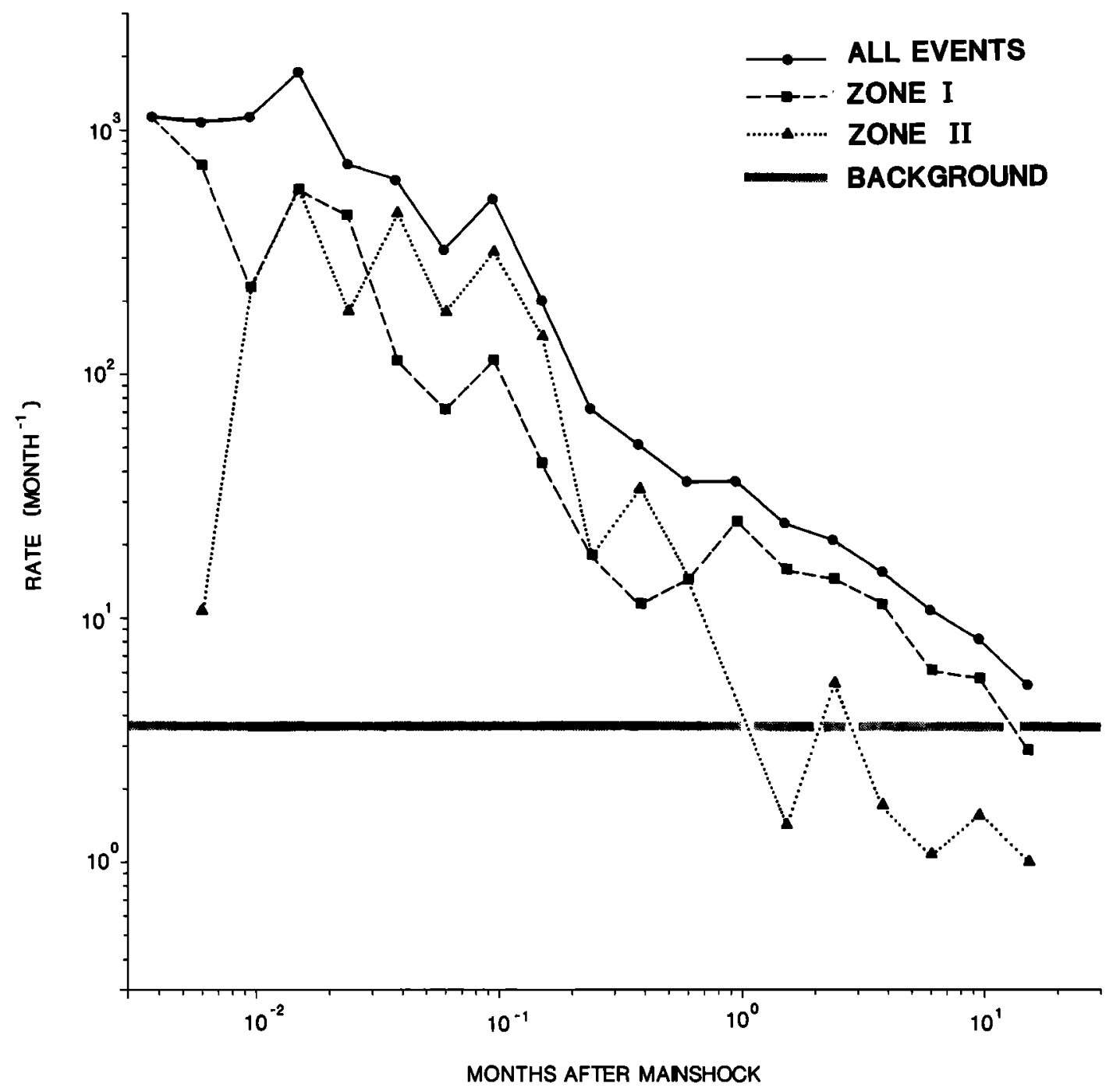

Fig. 10. Rates of earthquake ( $M \geq 1.5$ ) occurrence for the entire map area of Figure 3 , for zone I, and for zone II, as a function of time for the 18-month period following the mainshock. The rate of background seismicity for the entire map area for the period January 1, 1969, to August 5, 1979, is shown.

portion of zone I, which during the first 24 hours of the sequence marked the southeast edge of activity in this zone, now increase in frequency and advance $7 \mathrm{~km}$ southeast. This deep activity closely parallels and coincides in time with seismicity in zone II, undercutting it to the northeast. Seismicity on the central portion of zone I resumes about 10 days after the mainshock, after the considerably deeper slip along the southeast portion of the same zone has occurred. It also follows the southeastward migration of activity in zone II.

\section{RELATIONSHIP to LONGER-TeRm SEISMiCITY}

Thus far we have considered the Coyote Lake sequence in isolation. However, it is known that this segment of the Calaveras fault was seismically active well before the August 1979 earthquake [Bakun, 1980]. Continuous microearthquake monitoring that began in 1969 provides the basis for a detailed comparison of hypocentral locations for all events of $M \geq 1.5$ that occurred in the decade preceding the August 6,1979 , earthquake. The magnitudes of earthquakes occurring after April 27, 1977, have been increased by 0.1 unit to compensate for a systematic change in the network's measurement procedure. The locations of these events (Figures 12 and 13) show that the three main zones observed in the aftershock sequence were also active in the years before the Coyote Lake earthquake. Thus it is clear that the 1979 sequence involved movement on preexisting components of the composite fault zone. However, the gross distribution of events within the zones shows some significant variations before and after the event.

Perhaps the most significant feature of the preearthquake activity is the relative concentration of events at both ends of the aftershock zone [Bakun, 1980]. The localized concentration along the northern end of zone I is particularly prominent. The earthquakes of this spatial cluster began at least 10 years before the 1979 earthquake and occurred both as brief sequences and as isolated events (Figure 14). It is interesting to note that one such sequence occurred less than a day before the $M 5.11974$ Thanksgiving Day earthquake, located $20 \mathrm{~km}$ to the south-southeast, on the Busch fault, and activity in this zone was unusually high for several months thereafter. 

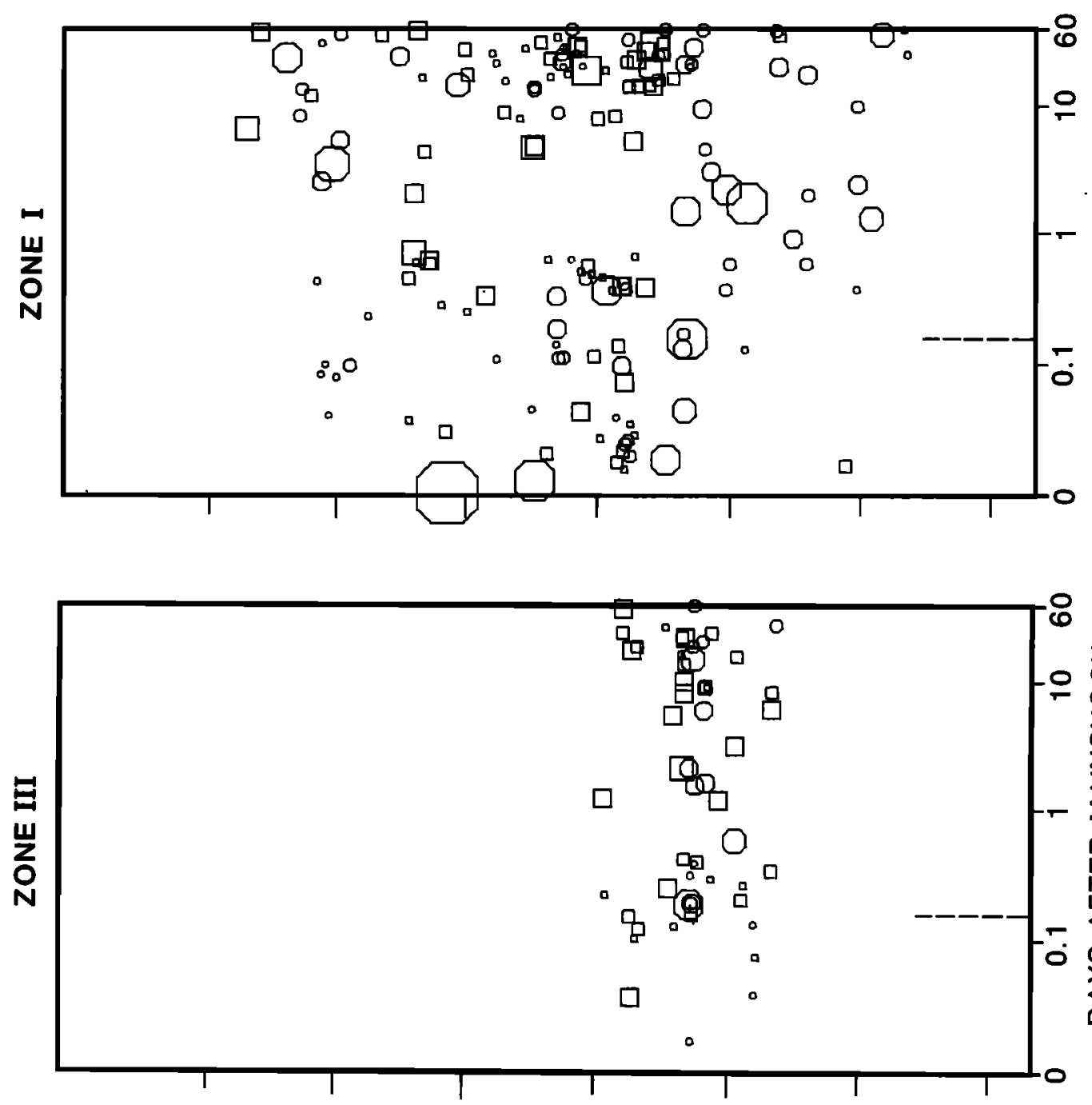

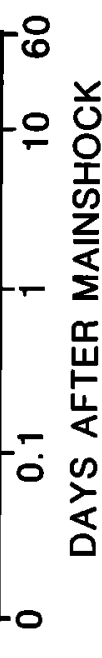

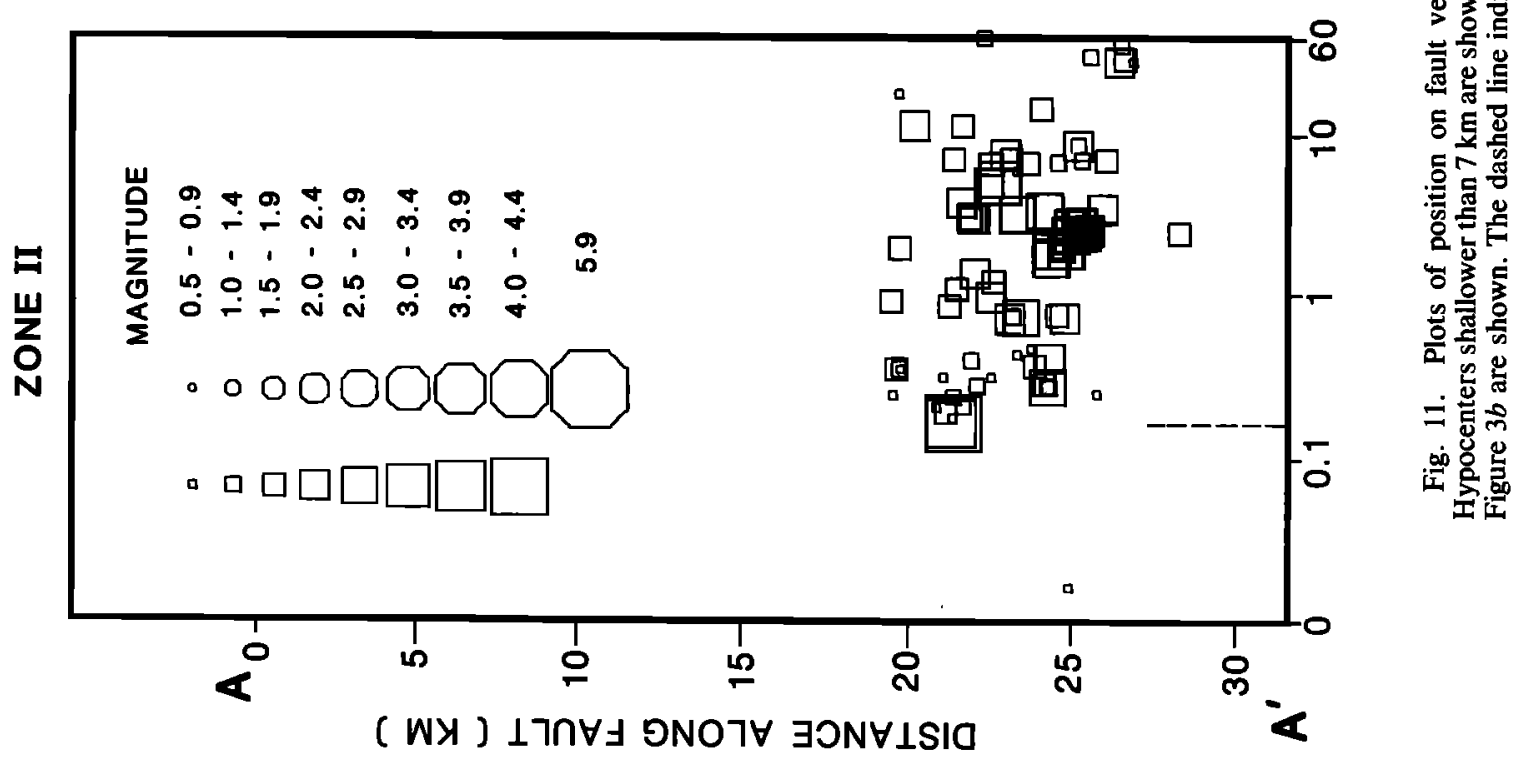




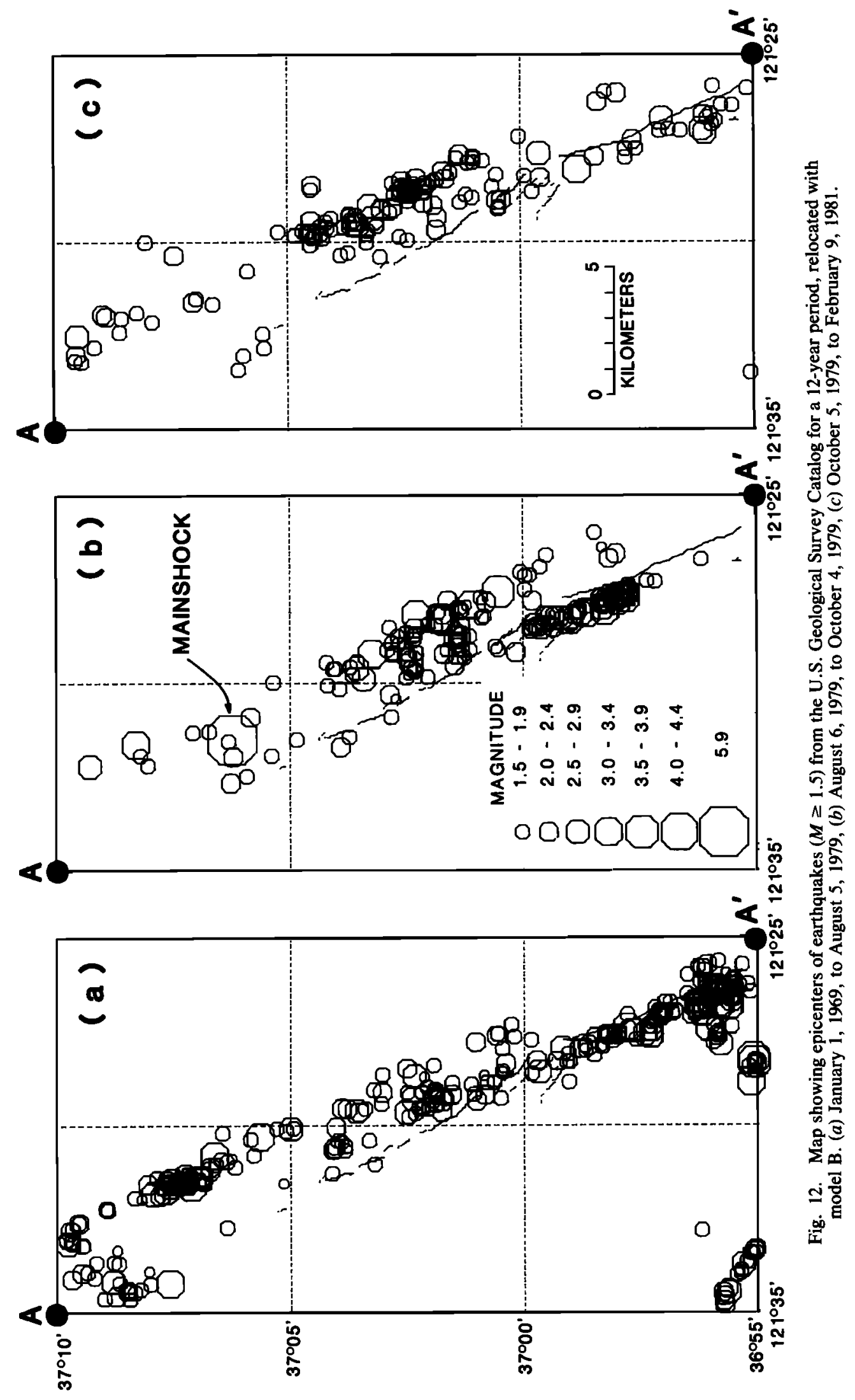




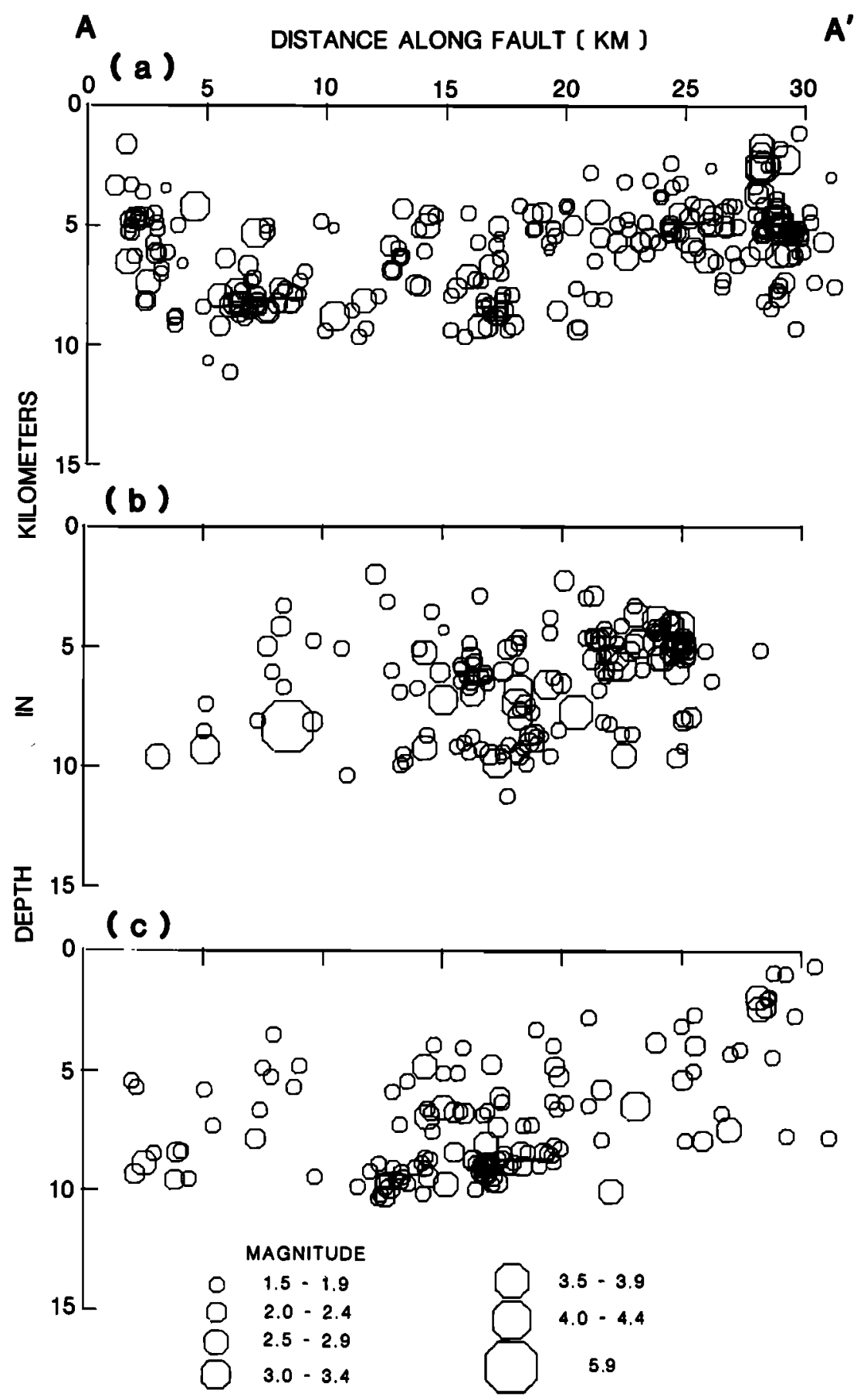

Fig. 13. Cross sections showing hypocenters of earthquakes in Figure 12. See Figure 12 caption for further explanation.

Within the resolution of these data the mainshock hypocenter locates exactly at the southeast end of the preearthquake, zone I cluster. This preearthquake source concentration falls within the central quiet portion of the aftershock zone and appears to have been obliterated by the mainshock. Conceivably, this cluster represents a critically stressed asperity or barrier that was particularly responsive to regional stress changes and that was relieved by slip in the mainshock. Similar concentrations of activity in the years preceding other moderate-sized California earthquakes have been observed elsewhere [e.g., Wesson and Ellsworth, 1973]. The central California earthquakes of February 24 and
27,1972 , clearly showed this type of preevent concentration of activity near the impending mainshock hypocenter [Ellsworth, 1975]. Ishida and Kanamori [1978] showed that the 1971 San Fernando, California, earthquake was preceded by a similar concentration of events located at or near the mainshock epicenter. They also presented evidence for a similar concentration of events in the epicentral region of the 1952 Kern County, California, earthquake [Ishida and Kanamori, 1980].

Taking a longer-term view of seismicity at Coyote Lake, we note that while this segment of the fault produces frequent small earthquakes, there is only one other earth- 


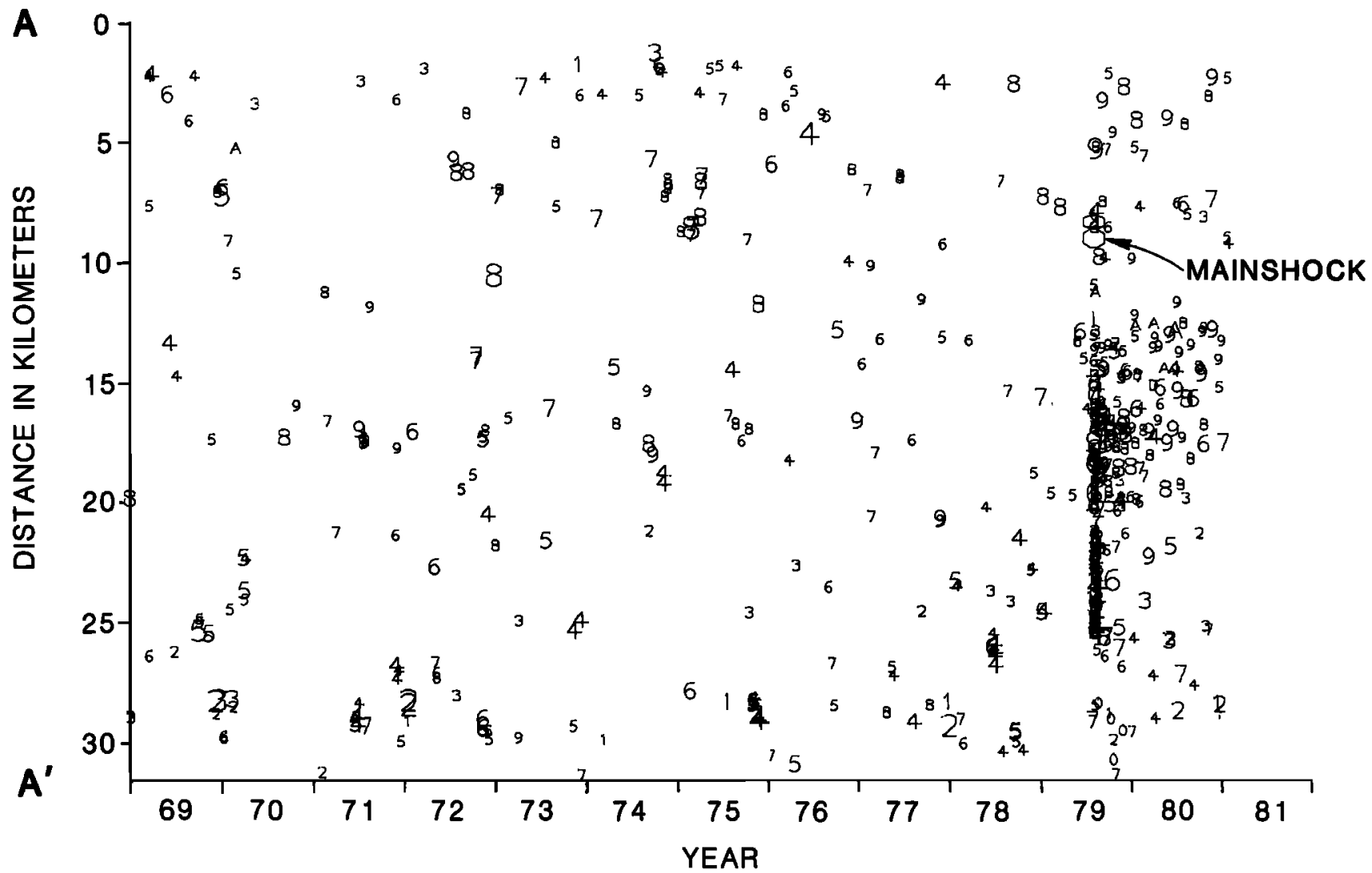

Fig. 14. Space-time plot of earthquakes $(M \geq 1.5)$ in the Coyote Lake region from January 1969 to February 1981. The section line $A-A^{\prime}$ is the same as in Figures 3,6,11, and 13. The symbol shown is the earthquake focal depth in kilometers (truncated). Symbol size is proportional to magnitude.

quake comparable in size to the 1979 event in the historic record. Historical accounts and intensity data analyzed by Toppozada et al. [1981] indicate that the $M 6$ earthquake of June 20, 1897, occurred along the same segment of the Calaveras fault system as the 1979 event. If the 1979 earthquake represents a repeat of the 1897 event, then it is possible that the hypocentral region of the fault was locked for as much as 82 years between events. This places an upper limit on the slip deficit accumulated between events of about $1.2 \mathrm{~m}$, assuming a loading velocity of $1.5 \mathrm{~cm} / \mathrm{yr}(\mathrm{M}$. Lisowski and N. E. King, unpublished data, 1982). Because the fault is creeping at the surface and appears to be moving in rigid block motion [Savage et al., 1979; Prescott et al., 1981], the total slip deficit could be much less, as the fault might be retarded but not totally locked in the hypocentral region. The dimension of any locked zone must be of limited spatial extent in order to satisfy the block motion requirement imposed by the geodetic data.

Such complications notwithstanding, the hypocentral region was undoubtedly locked for many years, as evidenced by the strong-motion recordings of the earthquake that indicate a main rupture dislocation of $1.2 \mathrm{~m}$ [ $\mathrm{Liu}$ and Helmberger, 1981]. While the coincidence of this estimate with the slip deficit is probably fortuitous, we suggest that the available evidence requires that the fault contain firstorder mechanical heterogeneity to produce infrequent strong earthquakes and highly clustered microseismicity within a general framework of rigid block motion.

\section{Discussion}

Models of faults usually possess geometries composed of a small number of planar elements. At long wavelengths, both the observed static displacement field and energy radiated from faults generally agree well with planar dislocation models. However, fault zones and earthquake ruptures, as mapped on the surface, are invariably more complex in character. In an elegant series of statistical studies of the spatial distribution of earthquakes, Kagan and Knopoff [1980] and Kagan [1981a, b] demonstrated that earthquake epicenters generally locate on planar structures but that a simple single-plane model may be inadequate to explain the higher-order moment function behavior of the distributions. Visual perception of mapped seismicity indeed suggests that earthquakes occur on multiple planar structures. To explain their observations of scale independence or self-similarity of the spatial distribution, they suggest a stochastic model in which earthquakes occur on an infinite number of planar faults, only the largest of which are resolved by seismic location. As a reference point for our discussion we shall introduce four simple conceptual models of faults that are motivated, in part, by the property of self-similarity. Each model has, at the smallest scale, a dislocation surface as its elemental form. The models considered are (1) a single quasi-planar slip surface, free of branches (a transverse cross section is a single continuous line), (2) a branched composite slip surface (a transverse cross section resembles a splayed fault trace), (3) an imbricate shear zone composed 
of unconnected slip surfaces (a transverse cross section is composed of en echelon stepping line segments), and (4) a shear zone in which discrete surfaces are numerous and relatively unclustered (a transverse cross section resembles a scattered field of line segments).

Each model has an obvious physical motivation and can be defined over a range of scale lengths appropriate to the data. Models 1, 2, and 3 suggest predominantly brittle deformation processes; in model 4 , significant aseismic deformation must accompany the seismic slip. Extension of the scale length range conceptually links each model with a self-similar counterpart.

Within this context we consider the implications of our observations for geometric models of the Coyote Lake earthquake. From both the spatial distribution of hypocenters and the focal mechanism solutions, on a scale of 3-30 $\mathrm{km}$, the faulting surface appears to be adequately described by two en echelon quasi-planar (model 1) dislocations. On a scale of $0.3-3 \mathrm{~km}$, finer departures from model 1 are apparent. Left stepping imbrication (model 3 ) is suggested in zone I, while in zone II the hypocentral distribution suggests a single right step. In zone III the geometry of faulting is perhaps least easily interpreted. The simple faulting of model 1 is not consistent with the observations of focal mechanisms and hypocenters, nor is there clear evidence for imbrication within this zone. While splay complications (model 2) emanating from the mainshock surface are suggested by the dextral fault plane solutions in Figure $8 b$, the hypocentral locations do not support this interpretation. With these observations, one cannot eliminate the possibility that faulting in zone III may consist of isolated brittle fractures scattered throughout a region of predominantly aseismic deformation (model 4).

Let us look in detail at the stresses present within the overlap zone. The model presented by Segall and Pollard [1980] provides a straightforward formulation of the stress field perturbations introduced by slip on multiple planar cracks in a homogeneous linear elastic material under uniform shear stress. For a vertical strike slip fault (their mode III crack) the radius within which the magnitude of the perturbing stress is greater than that of the applied stress $(\epsilon=0.5)$ is equal to the vertical dimension of the fault. Within this critical interaction distance, deformation is essentially controlled by the perturbing stress. Lower bounds on critical interaction distances for the fault surfaces in zones I and II inferred from the hypocentral distribution are thus approximately $8 \mathrm{~km}$ and $4 \mathrm{~km}$, respectively (Figure 6). Since the step offset between these two partially overlapping surfaces is about $2 \mathrm{~km}$, each fault segment is strongly under the influence of the stress perturbations introduced by slip on the other. The hypocentral resolution in this study allows identification with high certainty of a subset of aftershocks that locate strictly within the region bounded by the overlap of the two main slip surfaces (zone III in Figure $3 b$ ). Thus we can evaluate the applicability of the Segall and Pollard model in the vicinity of two interacting cracks qualitatively and to some degree quantitatively by comparing the details of the predicted stress field with the distribution and orientation of aftershocks in this critical zone.

The stress distribution between two overlapping right stepping echelon cracks was calculated by Segall and Pollard [1980] for the geometry shown in their Figure 9. The resulting rotation of $\sigma_{1}$ and failure condition contours are shown here in Figure 15. Failure contours for this case are similar to those for the nonoverlapping right-step case [Segall and Pollard, 1980, Figure 11d]. Failure can occur when $F>1$. The zone most likely to fail is a wide band connecting the crack tips. The epicenters in zone III map a structure resembling the $F \geq 2$ band (compare Figures $3 b$ and $7 b$ with Figure 15), although without certain identification of the main crack tips this observation must be considered tentative. The crack model used is two dimensional, while the hypocentral clusters suggest slip surfaces in zones I and II at significantly different but overlapping depth ranges (Figure $4 b$ ). Intuitively, the corresponding $F \geq 2$ zone of failure for the three-dimensional case at hand would be a dipping structure connecting the crack tips. The stereoscopic views in Figures $7 b$ and $8 b$ support this interpretation.

Studies of frictional sliding [e.g., Byerlee, 1968] indicate that shear fractures are most likely to occur on planes oriented approximately $60^{\circ}$ to the local minimum compression, $\sigma_{1}$. Figure 15 illustrates the clockwise rotation of $\sigma_{1}$ in the region surrounding the crack tips due to the presence of the cracks. The maximum perturbation of the local stress orientation occurs in the overlap zone, where $\sigma_{1}$ is rotated $15^{\circ}-20^{\circ}$ clockwise relative to the far-field minimum compression. The observed rotation of the average focal mechanism in zone III, relative to that in zones I and II, is in good agreement with the predicted stress perturbation. The total stress within the overlap zone is thus apparently more strongly controlled by the displacements on the bounding
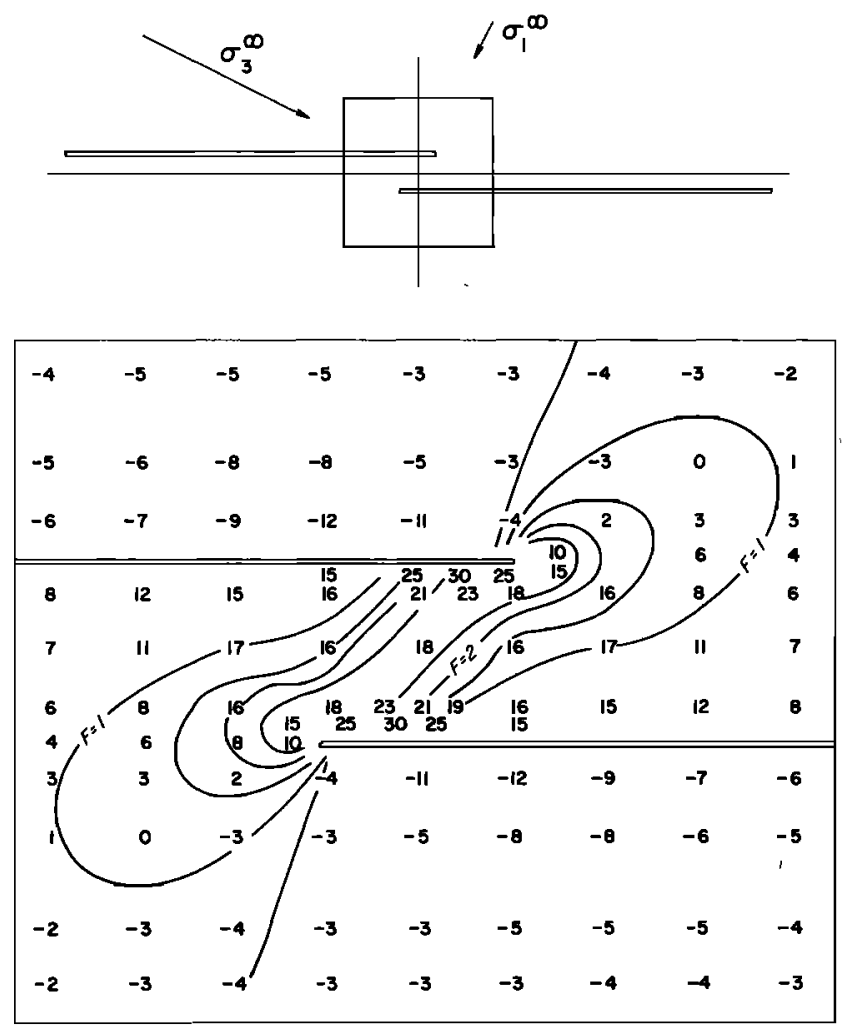

Fig. 15. State of stress calculated in the vicinity of the overlap of a right stepping en echelon pair of cracks having $d / a=0.1$ and $s / a=-0.1$ [See Segall and Pollard, 1980]. The diagram at the top illustrates crack geometry and applied stress. Numbers plotted indicate clockwise rotation in degrees of the minimum principal stress $\sigma_{1}$ relative to its orientation at infinity. Curved lines are contours of shear failure condition F [Segall and Pollard, 1980]. 
slip surfaces than it is by the far-field stress that drives the entire fault system.

The role of the geometry of a preexisting fault surface in controlling the progress and termination of a propagating shear rupture has been considered in several recent investigations. One well-studied example of a shear rupture thought to be controlled by fault geometry is the 1966 Parkfield, California, earthquake [Bakun and McEvilly, 1979; Segall and Pollard, 1980; Lindh and Boore, 1981]. There are several striking similarities between the fault geometries at Parkfield and at Coyote Lake. The relative size and position of the main and secondary slip planes and the location of the mainshock hypocenter and fault offset are virtually the same for these two earthquakes (compare Figure 6 with Lindh and Boore's [1981] Figure 15a). In both cases the rupture is interpreted to have proceeded toward the right step and terminated near it. Secondary slip thereafter occurred across the step on the en echelon segment. Within the overlap zone, evidence for clockwise rotation of principal stress orientation exists at Coyote Lake, from first-motion data, in the average strike of aftershock nodal planes and at Parkfield from near-field acceleration records, in the strike of an inferred dip slip secondary event occurring just after cessation of the main rupture [Lindh and Boore, 1981]. For these two events, then, the overlapping step in the fault essentially controlled the main rupture termination and significant features of the aftershock sequence.

On a finer scale, observations of both earthquakes suggest imbricate structure on the main rupture surface. At Parkfield, while not a statistically significant observation, the rotation by a few degrees of the average aftershock strike relative to the strike of the hypocentral clusters [Eaton et al., 1970 ] is consistent with a complex rupture surface possessing a fine-scale imbricate structure, as there appears to be on the main rupture at Coyote Lake.

It is tempting to generalize from these two earthquakes and to speculate that the observed complications in the fault geometry and rupture process arose from a mode of shear failure that is basically more complex than that suggested by the planar models heretofore considered. For example, gross strike slip or dip slip displacement may be entirely accommodated by displacements distributed over a complex, hierarchical system of en echelon or imbricate surfaces, over a wide range of length scales. An effect of such a geometry upon the modeled source parameters of the earthquake would be to increase the stress drop over that estimated for a simple planar model [Madariaga, 1979]. Numerous geologic examples of strike slip and dip slip faults exhibiting en echelon discontinuities at all length scales from $10^{-2}$ to $10^{5} \mathrm{~m}$ have been summarized by Segall and Pollard [1980].

From a statistical viewpoint the temporal development of the aftershock zone reflects the gross time behavior of the processes occurring after the mainshock. With time the zone expands in size through the activation of more distant elements of the fault system. This growth process is tempered by the rapid decline in event frequency, which effectively terminates the seismic strain redistribution process. The rates of decay of aftershock frequency for the entire sequence and for zone 1 alone are unusually low, while the rate for zone II is within the normally observed range of 0.9 $\leq h \leq 1.3$ [Mogi, 1962; Page, 1968]. A possible explanation for these low decay rates lies in the hypothesis that the seismicity of zone I may be composed of two or more secondary aftershock sequences with staggered starting times and normal decay rates. The abrupt decrease in the rate of decay of aftershock frequency in zone $I$ between approximately 0.5 and 1 month after the mainshock (Figures 10 and 11) may mark the onset of one such secondary sequence. This hypothesis is consistent with the suggestion of geometric complexity of the slip surface in zone $\mathrm{I}$, where the component branches of the suggested slip surface provide possible sites for subsequences of aftershocks. Alternatively, the earthquakes in zone I may represent a superposition of two or more processes with different time constants. For example, the process that controls aftershock sequences with normal frequency decay rates may be masked, in the cumulative occurrence rate, by a simultaneous, more slowly decaying process.

The fact that this portion of the Calaveras fault creeps suggests that during the 18 months after the mainshock, zone I may have been both creeping at an accelerated rate and eroding stress concentrations surrounding the main rupture. Surface slip along the fault estimated from geodetic measurements (M. Lisowski and N. E. King, unpublished data, 1982) for the 15 -month period beginning 3 days after the mainshock was 2.5-3 times greater in zones I and III than in zone II, while coseismic surface slip (that occuring during the 3 days following the mainshock) in zone II was 2-5 times greater than that in zones I and III. This contrast in the temporal development of surface slip is consistent with the hypothesis of continuing slip at depth in zones I and III, and not in zone II, during the aftershock period.

We turn now to the question of the dynamic interaction between the slip surfaces. Owing to the presence of an approximately $3^{\circ}$ azimuthal angle between the strikes of the two main hypocentral clusters, zone II lies in a volume expected to undergo a reduction of normal stress and an increase in shear stress in response to dextral slip in zone I [Segall and Pollard, 1980]. Induced slip in zone II is therefore an expected consequence of the mainshock rupture. Similarily, the portion of zone I experiencing a complete hiatus of activity 1-9 days after the mainshock lies in a volume expected to undergo an.increase in normal stress in response to dextral slip on zone II. The deep activity in zone I south of $37^{\circ} \mathrm{N}$ occurs in a volume expected to undergo an increase in shear stress in response to the shallow slip in zone II (see, for example Chinnery [1963, Figure 4a]). Apparently, a complex sequence of displacements, as inferred from the seismic activity, began with the mainshock rupture. The resulting stress redistribution triggered a separate slip sequence that began 5.5 hours later in zone II (Figure 11). The displacement in zone II, in turn, introduced a local stress perturbation that temporarily locked the central portion of zone I. This alternation of displacement on zones I and II resembles the behavior of a frictional escapement, a mechanism of stress reduction with intermittent motion characteristic of some coupled mechanical systems (see, for example, Bickford [1972]).

In conclusion, these observations of the Coyote Lake earthquake sequence suggest that the fault structure is geometrically complex and that the displacements that occur on its component surfaces are part of a self-interacting system of stress redistribution. Observed space-time modulation of the aftershock activity on branches of the fault structure is qualitatively consistent with local stress field perturbations predicted by a simple crack-stress model and 
modeled seismic displacements. Observed rotation of fault orientation within the overlap zone is in quantitative agreement with the same model. The picture of the fault zone that emerges is one of a geometrically complex slip surface structure sustaining asynchronous displacements on its component parts.

Acknowledgments. We are most grateful for the invaluable assistance provided by Amy Rapport in the preparation of the data. We also gratefully acknowledge many stimulating discussions with J. Andrews, A. Aydin, W. Bakun, R. Daniel, D. Herd, A. Lindh, D. Oppenheimer, D. Pollard, P. Segall, R. Stein, and C. Stephens, among others. We thank W. Bakun, R. Stein, P. Segall, and two anonymous reviewers for critical reviews of the manuscript.

\section{REFERENCES}

Bakun, W. H., Seismic activity on the southern Calaveras fault in central California, Bull. Seismol. Soc. Am., 70, 1181-1197, 1980.

Bakun, W. H., and T. V. McEvilly, Earthquakes near Parkfield, California: Comparing the 1934 and 1966 sequences, Science, 205, 1375-1377, 1979.

Bakun, W. H., R. M. Stewart, C. G. Bufe, and S. M. Marks, Implication of seismicity for failure of a section of the San Andreas fault, Bull. Seismol. Soc. Am., 70, 185-201, 1980.

Bickford, J. H., Mechanisms for Intermittent Motion, pp. 152-180, Industrial Press, New York, 1972.

Bouchon, M., The rupture mechanism of the Coyote Lake earthquake of August 6, 1979, inferred from near-field data, Bull. Seismol. Soc. Am., 72, 745-758, 1982.

Brady, A. G., P. N. Mork, V. Perez, and L. D. Porter, Processed data from the Gilroy array and Coyote Creek records, Coyote Lake, California earthquake 6 August 1979, U.S. Geol. Surv. Open File Rep., 81-42, 1981.

Byerlee, J. D., Brittle-ductile transition in rocks, J. Geophys. Res., $73,4741-4750,1968$.

Chinnery, M. A., The stress changes that accompany strike-slip faulting, Bull. Seismol. Soc. Am., 53, 921-932, 1963.

Crosson, R. S., Crustal structure modeling of earthquake data, 1 , Simultaneous least squares estimation of hypocenter and velocity parameters, J. Geophys. Res., 81, 3036-3046, 1976.

Eaton, J. P., M. E. O'Neill, and J. N. Murdock, Aftershocks of the 1966 Parkfield-Cholame, California, earthquake: A detailed study, Bull. Seismol. Soc. Am., 60, 1151-1197, 1970.

Ellsworth, W. L., Bear Valley, California, earthquake sequence of February-March, 1972, Bull. Seismol. Soc. Am., 65, 483-506, 1975.

Engdahl, E. R., and W. H. K. Lee, Relocation of local earthquakes by seismic ray tracing, J. Geophys. Res., 8I, 4400-4406, 1976.

German, P., and C. Johnson, STEREO: A computer program for projecting and plotting stereograms, U.S. Geol. Surv. Open File Rep., 82-726, 1982.

Healy, J. H., and L. G. Peake, Seismic velocity structure along a section of the San Andreas fault near Bear Valley, California, Bull. Seismol. Soc. Am., 65, 1177-1197, 1975.

Ishida, M., and H. Kanamori, The foreshock activity of the 1971 San Fernando earthquake, California, Bull. Seismol. Soc. Am. $68,1265-1279,1978$.

Ishida, M., and H. Kanamori, Temporal variation of seismicity and spectrum of small earthquakes preceding the 1952 Kern County, California earthquake, Bull. Seismol. Soc. Am., 70, 509-527, 1980.

Kagan, Y. Y., Spatial distribution of earthquakes: The three-point moment function, Geophys. J. R. Astron. Soc., 67, 697-717, $1981 a$.

Kagan, Y. Y., Spatial distribution of earthquakes: The four-point moment function, Geophys. J. R. Astron. Soc., 67, 719-733, $1981 b$.
Kagan, Y. Y., and L. Knopoff, Spatial distribution of earthquakes The two-point correlation function, Geophys. J. R. Astron. Soc., $62,303-320,1980$.

King, N. E., J. C. Savage, M. Lisowski, and W. H. Prescott, Preseismic and coseismic deformation associated with the Coyote Lake, California, earthquake, J. Geophys. Res., 86, 892-898, 1981.

Lee, W. H. K., D. G. Herd, V. Cagnetti, W. H. Bakun, and A. Rapport, A preliminary study of the Coyote Lake earthquake of August 6, 1979 and its major aftershocks, U.S. Geol. Surv. Open File Rep., 79-1621, 1979.

Lindh, A. G., and D. M. Boore, Control of rupture by fault geometry during the 1966 Parkfield earthquake, Bull. Seismol. Soc. Am., 7I, 95-116, 1981.

Liu, H. L., and D. V. Helmberger, Near source ground motion of the August 6, 1979 Coyote Lake, California earthquake (abstract), Eos Trans. AGU, 62, 972-973, 1981.

Madariaga, R., On the relation between seismic moment and stress drop in the presence of stress and strength heterogeneity, $J$. Geophys. Res., 84, 2243-2250, 1979.

McNally, K. C., and T. V. McEvilly, Velocity contrast across the San Andreas fault in central California: Small scale variations from $P$-wave nodal plane distortion, Bull. Seismol. Soc. Am., 67, 1565-1576, 1977

Mogi, K., On the time distribution of aftershocks accompanying the recent major earthquakes in and near Japan, Bull. Earthquake Res. Inst. Tokyo Univ., 40, 107-124, 1962.

Nabelek, J., and M. N. Toksöz, Applications of WWSSN seismograms to the study of the Coyote Lake earthquake of August 6 , 1979 (abstract), IASPEI Meeting, Int. Assoc. Seismol. and Phys. of the Earth's Inter., London, Ont., 1981.

Page, R., Aftershocks and microaftershocks of the great Alaska earthquake of 1964, Bull. Seismol. Soc. Am., 58, 1131-1168, 1968.

Poupinet, G., F. Glangeaud, and P. Côte, $P$-time delay measurement of a doublet of microearthquakes, in IEEE International Conference on Acoustics, Speech, and Signal Processing 82, Paris, pp. 1516-1519, Institute of Electrical and Electronics Engineers, New York, 1982.

Prescott, W. H., M. Lisowski, and J. C. Savage, Geodetic measurement of crustal deformation on the San Andreas, Hayward, and Calaveras faults near San Francisco, California, J. Geophys. Res., 86, 10853-10869, 1981.

Reasenberg, P., Comparison of performance of automatic and human $\boldsymbol{P}$-picking systems using a common data set (abstract), Eos Trans. $A G U, 6 l, 1030,1980$.

Savage, J. C., W. H. Prescott, M. Lisowski, and N. E. King, Geodetic measurements of deformation near Hollister, California, 1971-1978, J. Geophys. Res., 84, 7599-7615, 1979.

Segall, P., and D. D. Pollard, Mechanics of discontinuous faults, $J$. Geophys. Res., 85, 4337-4350, 1980.

Spieth, M. A., Two detailed seismic studies in central California, Ph.D. thesis, Stanford Univ., Stanford, Calif., 1981.

Thurber, C. H., Earth structure and earthquake locations in the Coyote Lake area, central California, Ph.D. thesis, Mass. Inst. of Technol., Cambridge, 1981.

Toppozada, T. R., C. R. Real, and D. L. Parke, Preparation of isoseismal maps and summaries of reported effects for pre-1900 California earthquakes, Calif. Div. Mines Geol. Open File Rep., 81-II SAC, 182 pp., 1981.

Uhrhammer, R. A., Observations of the Coyote Lake, California earthquake sequence of August 6, 1979, Bull. Seismol. Soc. Am., $70,559-570,1980$.

Wesson, R. L., and W. L. Ellsworth, Seismicity preceding moderate earthquakes in California, J. Geophys. Res., 78, 8527-8546, 1973.

(Received April 28, 1982;

revised July 26,1982 ;

accepted September 3, 1982.) 